ISSN: 2146-3042

DOI:

\title{
Covid-19’un İşletme Fonksiyonlarına Etkileri: Öğrenci Görüşlerine Yönelik Bulgular*
}

Ali İhsan AKGÜN**

\section{ÖZET}

Bu çalışma, Ankara Yıldırım Beyazıt Üniversitesi'ndeki sağllk yönetimi lisans ve yüksek lisans öğrencilerinin İşletme I dersinde işletme fonksiyonlarını ögrrenmeye ilişkin bilgi edinmelerine yönelik görüşlerini incelemektedir. Bu çalışmanın amacı, Covid-19'un işletme fonksiyonlarına yaptığı etkileri öğrenci görüşleri bakış açısıyla incelemektir. Çalışmada, veri toplama aracı olarak, Ankara Yıldırım Beyazıt Üniversitesi Uzaktan Ĕ̈itim Araştırma ve Uygulama Merkezi (AYBUZEM) sinav uygulamaları kullanılmıştır. Bu çalışmanın bulguları, Covid-19 krizinin oldukça karmaşık olduğu ve sadece mevcut iş modellerinde değişikliklere değil, aynı zamanda ekonomi, iş dünyası ve toplumdaki geçişleri anlama ve gözlemleme ihtiyacına da neden olmasıdır. Bu çalışmanın bulgularına göre, Covid-19 krizini hafifletmek için yöneticilerin ileriye dönük düşünmeye, yeni stratejilere ve çeşitli cephelerde yeniden planlamaya ihtiyaç duyduğunu göstermektedir. Ayrıca, bu çalıșma aynı zamanda yöneticilerin, büyüme için doğru büyüme stratejilerine ulaşmak için ileri teknolojilere, tedarik zinciri esnekliğine ve organizasyonel dinamiğe olan ihtiyacı öngörmelerini sağlar.

Anahtar Kelimeler: İşletme Fonksiyonları, İşletme Modellerinin Değişimi, Covid-19, Öğrenci Görüşleri.

JEL Sinıflandırması: G15, M40, M49

\section{The Effects of Covid-19 on Business Functions: Evidence from Student Opinions}

\section{ABSTRACT}

This study examines a knowledge acquisition for business functions learning for Management I in the health management of the opinions of undergraduate and graduate students at the Ankara Yildirim Beyazit University. The purpose of this study examines the effects of Covid-19 on business functions from the perspective of student opinions. In this study, Ankara Yildirlm Beyazit University Distance Education Research and Application Center (AYBUZEM) exam applications were used as data collection tool. According to the findings of this study, the Covid-19 crisis is highly complex and causes not only changes in existing business models, but also the need to understand and observe shifts in the economy, business and society. This study shows that to alleviate the Covid-19 crisis, managers need forward thinking, new strategies, and replanning on various fronts. Additionally, this study also provides managers anticipate the need for advanced technologies, supply chain flexibility, and organizational dynamism to reach the right growth strategy for growth.

Keywords: Business Functions, Shifts of Business Models, Covid-19, Student Opinions.

Jel Classification: G15, M40, M49

* Bu makale, 23-25 Nisan 2021 tarihleri arasında gerçekleştirilen VI. Uluslararası Muhasebe ve Finans Sempozyumunda bildiri olarak sunulmuştur.

Makale Gönderim Tarihi: 06.05.2021, Makale Kabul Tarihi: 09.06.2021, Makale Türü: Nitel Araştırma

** Prof.Dr., Ankara Yıldırım Beyazıt Üniversitesi, Sağlık Yönetimi Bölümü, ihsan.akgun@ybu.edu.tr, ORCID: 0000-0002-6441-8196. 


\section{GíRiş}

Covid-19, insan varoluşunun özünü tehdit eden sosyal ve ekonomik bir kriz olup, dünya çapında kontrolsüz bir şekilde yayılmaya devam etmektedir. Bulaş salgınına yanıt olarak, birçok ülkenin liderleri, ülkelerinde ani veya aşamalı kısıtlamalar ilan ederek ekonomiyi kurtarmadan önce hayatları kurtarmaya karar vermişlerdir. Sosyal mesafe ve evde kalma gibi politikalar anlık olarak uygulanmış olup, bu da sektörler genelinde birçok işletmede ciddi şekilde zarara yol açmıştır. Böylece, azalan işletme gelirleri ve yüksek düzeyde belirsizlik göz önüne alındığında, dünya çapında çoğu işletme için finansal çarkların döndürülmesi güçleşmektedir (Verma ve Gustafsson, 2020: 253).

Covid-19 krizi, bir yandan ticari kuruluşlara güçlükleri beraberinde getirirken, diğer yandan yeniliklere ihtiyaç duyarak kuruluşlara krizde hayatta kalmalarına olanak sağlayacak yeni iş modelleri belirleme firsatları sunmaktadır (Seetharaman, 2020: 1). Covid-19, ayrıca, dünya çapındaki işletmeleri daha yeni ve daha sürdürülebilir bir şekilde hızla çalışmaya yöneltmiştir. Firmalar, gerçek zamanlı karar verme, işgücü üretkenliği, iş sürekliliği ve güvenlik riskleri gibi eski güçlüklere yanıt olarak önceliklerini değiştirdikçe, pandeminin getirdiği yeni güçlükler gelecekte işletmelerin dayanıklılığını analiz etmelerine imkan tanımıştır (Verma ve Gustafsson, 2020: 253).

Bir sağlık krizinin ekonomik krize dönüşmesine yönelik olarak başlıca iki ana neden vardır. Birincisi, virüsün yayılması sosyal mesafeyi teşvik etmiş ve bu da finansal piyasaların, şirket ofislerinin, işletmelerin ve etkinliklerin kapanmasına yol açmıştır. İkincisi, virüsün yayılmakta olduğu oran ve durumun ne kadar kötüye gidebileceğine dair artan belirsizlik, tüketiciler, yatırımcılar ve uluslararası ticaret ortakları arasında tüketim ve yatırımda güvenliğe yönelmeye yol açmıştır. Ampirik bulgular, artan kısıtlama günleri, para politikası kararları ve uluslararası seyahat kısıtlamalarının iktisadi faaliyet düzeyini ve büyük borsa endekslerinin kapanış, açılış, en düşük ve en yüksek hisse senedi fiyatını ciddi şekilde etkilediğini ortaya koymaktadır (Ozili, 2020: 1). Dolayısıyla, Covid-19'un hızlı yayılması, tüm dünyadaki finansal piyasalar üzerinde önemli etkilere sebep olmuştur.

Covid-19 salgını, birçok işletmeyi kapanmaya zorlamış ve çoğu endüstri sektöründe benzeri görülmemiş bir ticaret kesintisine yol açmıştır. İşletmeler, sağlık ve güvenlik, tedarik zinciri, iş gücü, nakit akışı, tüketici talebi, satış ve pazarlama ile ilgili olan işletme fonksiyonlarına yönelik birçok kısa vadeli güçlüklerle karşı karşıya kalmışlardır. Bununla birlikte, bu güçlüklerin başarılı bir şekilde üstesinden gelmek için, tüm organizasyonlar, mevcut ortama değer getirmeyecek harcamaları önceliklendirmek ve optimize etmek veya görevleri ertelemeyi tercih etmişlerdir (Donthu ve Gustafsson, 2020: 284).

Literatürde, Covid-19'un işletmeler üzerindeki etkileri bağlamında işletmelerin hisse senedi getirileri ve dünya çapındaki borsalar üzerindeki olumsuz etkileri hususunda çeşitli çalışmalar yapılmıştır. Covid-19'un hisse senetlerine etkileri konusunda bir çok çalışma olmasına rağmen (Al-Awadhi vd., 2020; Ashraf, 2020; Alfaro vd., 2020), bu salgının işletme fonksiyonlarına etkisi konusunda Sheth (2020)'nın müşteri davranışlarına etkileri ile Vasanhi ve Basariya (2020)'nın insan kaynakları fonksiyonuna etkileri hariç henüz bir çalışmaya rastlanılmamıştır. Covid 19 ile ilgili bir başka çalışma ise onun ekonomik etkileri konusunda yapılan çalışmalardır. Bunların başlıcaları; Covid-19'un ekonomik etkilerin değerlendirilmesi (Eroğlu, 2020; Fernandes, 2020), uzun vadeli etkilere yönelik sonuçlar (Jorda et al., 2020), 
global ekonomiye etkileri (Özili ve Arun, 2020) ve işletme alanına ait Covid-19 döneminde eğitim faaliyetlerine yönelik, örneğin muhasebe eğitimine ilişkin (Akgün, 2020) olmak üzere bir çok çalışma vardır.

$\mathrm{Bu}$ çalışmada, Ankara Yıldırım Beyazıt Üniversitesi Sağlık Bilimleri Fakültesinin Sağl1k Yönetimi bölümünde eğitim gören lisans ve lisansüstü öğrencilerinin Covid-19'un işletme fonksiyonlarına etkilerine yönelik görüşlerinin genel bir değerlendirmesi yapılmış ve gelecekteki işletme yöneticilerine yönelik öneriler ortaya konmuştur. Uygulayıcıların ve araştırmacıların salgının gelecekteki işletmelerin finansal büyüme üzerindeki etkisini anlamalarına yardımcı olmak için, bu çalışma aşağıdaki araştırma sorusunu ele almaktadır. Covid-19'un işletmelerin fonksiyonlarına yönelik etkileri ile ilgili güncel odak noktaları nelerdir?

$\mathrm{Bu}$ çalışmada, öncelikle Covid 19'un işletmelere ve ekonomiye olan etkileri ele alındıktan sonra, işletme fonksiyonları sırasıyla tedarik ve üretim, pazarlama, muhasebe ve finansman, insan kaynakları, AR-GE, yönetim ve halka ilişkiler fonksiyonu bağlamında incelenmiştir. Ayrıca, çalışmada araştırmanın yöntemi ve araştırmaya ilişkin öğrenci görüşlerine yönelik bulgulara yer verilmiştir.

\section{LITERATÜR TARAMASI}

\subsection{Covid-19’un İşletmelere Etkileri}

Covid-19'un ekonomik açıdan etkileri, hem toplam talep hem de arzdaki ani düşüşlerde ortaya çıkmıştır. Salgını kontrol altına almak için işyerlerinin yaygın olarak kapatılması, toplam arzda düşüşe neden olurken, tüketim ve yatırımdaki azalma talebin düşmesine neden olmuştur (Seetharaman, 2020: 1). Covid-19'un ekonomik etkileri finansal sistemi de etkilemektedir. Özellikle Covid-19 ile; enfekte olanların tıbbi tedavisinin hem kamu hem de özel sağlık sistemine olan maliyetleri ve salgının kontrolü ile daha rutin sağlık sorunları ile eşzamanlı olarak başa çıkamamanın sağlık sistemleri üzerindeki oluşturduğu yük, istihdamdaki azalma, ekonomik faaliyeti bozan sosyal mesafe, turizme olan etkisi ve doğrudan yabancı yatırım üzerindeki etkisi başlıca ekonomik endişeleri yansıtmaktadır (Goodel, 2020: 1-2).

Covid-19 salgınının kısa vadeli en belirgin ekonomik etkileri, birçok ülkenin katı karantina politikaları benimsemesi ile, ekonomik faaliyetlerin önemli ölçüde sınırlandırılmasıdır. Covid-19'un uzun vadeli olarak etkileri ise, kitlesel işsizlik ve işletme başarısızlıklarına yol açabilir. Örneğin, diğer sektörlerde olduğu gibi turizm ve havacılık gibi bazı işletmeler güçlüklerle karşılaşmıştır. Küresel ekonomik etkileri tam olarak henüz netlik kazanmasa da, finans piyasaları şimdiden dramatik hareketlerle buna karşılık vermektedir. Buna yönelik olarak, Mart 2020'de ABD borsas1, 1997 Asya krizinden sonra önemli ölçüde düşüş yaşamıştır. ABD'deki çöküşle birlikte, Avrupa ve Asya'daki borsalar da \%10'dan fazla düşüş kaydetmiştir (Zhang vd., 2020: 1). Dolayısıyla , kurumsal krizlere ve hatta iflasa yol açabilecek şüpheli alacakların artması ve büyük ölçekli iflas riskinin yüksek olması nedeniyle, finans şirketlerinin hisse senetlerinin bir pandemi sırasında borsalarda en önemli şekilde etkilenen menkul kıymetler olduğu söylenebilir (Anh ve Gan, 2020: 11).

Yapılan ampirik çalışmalarda, örneğin, Al-Awadhi vd. (2020), Covid-19’un Çin'deki 
tüm firmaların hisse senedi getirilerini olumsuz etkilediğini ortaya koymuştur. Ashraf (2020), salgının 64 ülkede borsa performansı üzerindeki etkisini araştırmış ve hisse senedi getirileri ile Covid-19 arasında ters ilişkiler bulmuştur. Alfaro vd. (2020), Covid-19 'un ABD hisse senedi getirileri üzerindeki olumsuz etkilerini göstermektedir. Zhang vd. (2020), Covid-19 'un Mart 2020'de on ülkenin borsaları ve Japonya, Kore ve Singapur borsaları üzerindeki olumsuz sonuçlarını ortaya koymuştur. Benzer olarak, He vd. (2020) ve Liu vd. (2020), Covid-19 'un birden fazla ülkenin borsalarındaki sonuçlarını değerlendirmiş ve salgının hisse senedi getirileri üzerinde olumsuz bir etkisi olduğunu bulmuşlardır.

Bununla birlikte, Covid-19 salgınının hisse senetleri üzerindeki etkileri, sektörler arasında farklılık göstermiştir. Örneğin, Schoenfeld (2020), Covid-19 nedeniyle borsalarda en kötü etkilenen sektörlerin gaz ve petrol, giyim, otomobil, ulaşım, makine ve konaklama sektörleri olduğunu ifade etmiştir. Ayrıca, dünya genelinde konaklama sektörü, tüketicileri restoran ve kafelerden uzak durmaya zorlayan birçok ülkenin benimsediği kısıtlama önlemleri nedeniyle önemli bir olumsuz etkiyle karşı karşıya kalmıştır. Kısıtlama nedeniyle, restoran müşterileri tercihlerini şirket dişında yemek yeme, arabada yiyecek yeme, işte yemek için hazır yemekler tercih etmelerine neden olmuştur (Seetharaman, 2020:3).

Covid-19, bilgi teknolojisi hizmetleri gibi bazı hizmet sektörlerinde çalışanlar evden çalıştıkları için bu sektördeki işletmelerin kalıcı olarak kapanma riski bulunmaktadır (Verma ve Gustafsson, 2020: 256). Böylece, bu krizin yetkililer tarafından koordine edilmesi için alınması gereken birincil önlem, özellikle işletmelerin kapasitesini geliştirmeye yönelik ek kamu fonları sağlanmasıdır. İkincisi, koronavirüs krizinin olumsuz etkileriyle başa çıkmalarına yardımcı olmak için kişilere, girişimcilere ve şirketlere finansal destek sağlanmalıdır. Üçüncüsü, işçilerin toplu işten çıkarılmasını önlemek için işverenlere kriz sırasında istihdamı korumaları için teşvikler verilmelidir. Son olarak, bankaların, işletmelerin yerel finansal piyasalarda kredi ve likidite sıkışıklığını önlemek için likidite ve kredi desteği vermeleri gerekir (Ozili and Arun, 2020: 1). Söz konusu tedbirlere yönelik olarak, Türkiye’de de muhtelif tarihlerde önlemler alınmıştır.

Covid-19'un küçük ve orta ölçekli işletmeler üzerindeki ekonomik etkisi, birincil ve ara girdi kaynağı birçok faktöre bağlı olarak sektörler ve firmalar arasında farklılık göstermektedir. Bu bağlamda, küresel tedarik zincirine en fazla maruz kalan bu tür küçük ve orta ölçekli işletmeler, diğerlerinden daha fazla destek almalıdır. Ayrıca, krizler sırasında işsizlik risklerini azaltmak için yeni yasal düzenlemeler oluşturulmalıdır (Ozili, 2020: 8). Bu tür yasalar, ailelerin gelirinin korunmasına, işçilerin üretken kapasitesinin ve işletmelerin beşeri sermayesinin ve genel ekonominin korunmasına yardımcı olma şeklinde olabilir.

Covid-19 salgını, petrole olan talebin azalmasıyla ekonomik durumu daha da kötüleştirmiştir. Salgın sırasında insanların ve malların hareketinde bir azalmaya yol açan seyahat kısıtlamaları, havacılık yakıt1, kömür ve diğer enerji ürünlerine olan talebin düşmesine neden olmuş ve bu da düşük talep nedeniyle petrol fiyatlarında düşüşe neden olmuştur. Böylece, petrol fiyatındaki küresel düşüş, uluslararası pazarda petrol ürünlerine olan düşük talep ile birleştiğinde petrole bağımlı ülkelerde petrol gelirlerinde önemli bir düşüşe yol açtı, bu da cari açıkları artırarak petrole bağımlı birçok ülkenin ödemeler dengesi pozisyonunu kötüleştirmiştir (Ozili ve Arun, 2020: 8). Sonuç olarak, petrole bağımlı bazı ülkelerin ulusal bütçesi, bazı ülkeleri ya bütçe açıklarını finanse etmek için IMF, Dünya Bankası ve diğer borç veren kuruluşlardan dış kredi almaya zorlayan büyük açıklarla 
karşılamasına ya da küresel pazardaki mevcut düşük petrol fiyatı kullanılarak fiyatlandırılan yeni bir bütçe oluşturmak zorunda kalmalarına neden olmuştur.

Covid-19'un etkilerinin bir diğeri ise, ithalata bağımlı birçok ülke görülmüştür. Küresel tedarik zincirinden gelen malların azalması ve ithal mallar için Çin'e büyük ölçüde güvenilmesi ve ayrıca Çin'de ihracat fabrikalarının çoğunun kapanması, ithalata bağımlı ülkelere tedarik sıkıntısına yol açmıştır (Ozili ve Arun, 2020: 9). Ayrıca pandemi sırasında, ticaret kısıtlamalarının yarattığı fiyat artışları bazı durumlarda vatandaşların tıbbi malzemelere erişimini engelleyebilmektedir. Bu sebeple, acil bir durum olarak, hükümetler COVID-19 ile ilgili tıbbi malzemelerin ithalatına yönelik politikalarını gözden geçirmelidir (Evenett, 2020: 838).

Covid-19'un Türkiye ekonomisi bağlamındaki etkisi, pandemi öncesi yaşanan döviz krizinin etkisinin boyutu açısından önem taşımaktadır. Türkiye ekonomisinin yapısal sorunlarından birisi "dış sermaye girişlerine bağımll, borç artışına dayanan ve inşaat odaklı bir büyüme modeline” sahip olmasında ortaya çıkmaktadır. Söz konusu model küresel likidite düzeyine dayalı olarak parasal genişleme ve daralma süreçlerinden etkilenmekte ve ekonominin kırılgan bir yapıya sahip olmasına yol açmaktadır. Ancak, 2013 yılından itibaren Amerika Merkez Bankası'nın (FED) oransal genişleme programına son vereceğini açıklamasıyla, Türkiye’ye yönelik sermaye girişlerinde bir duraklama meydana gelmiştir. Bu durum Türkiye Cumhuriyeti Merkez Bankası'nın (TCMB) faizleri arttırmasıyla yurt içi faiz ve borç artısına dayalı büyüme modeli için önemli güçlükleri beraberinde getirmektedir. Böylece, ekonomideki bu kırılgan yapıya bağlı olarak, 2018 yılına gelindiğinde daha da belirgin hale dönüşmüş ve ani para çıkışları ve spekülatif dalgalanmayla Türk Lirasının önemli değer kaybettiği bir döviz krizine yol açmıştır (Orhangazi, 2020: 199-211). Dolayısıyla, Türkiye'nin pandemi sürecinin etkilerine 2018 döviz krizinin etkileriyle mücadele içerisinde olduğu bir dönemde girdiği söylenebilir. Buna ek olarak, ekonomideki makro göstergeler pandeminin etkisinin görülmesi açısından önemli bir işarettir. Cumhurbaşkanlığı Strateji ve Bütçe Başkanlığı'nın yayınladığı verilere göre, Türkiye ekonomisinin büyüme rakamlarının 2018'in son çeyreğinden itibaren küçülmeye başladığ 2019'un son çeyreği ile artış trendine girdiği ama pandemi süreciyle önemli bir düşüş yaşadığı görülmektedir. İşsizlik rakamlarına bakıldığında ise, Türkiye İstatistik Kurumu (TÜIKK) verilerine göre, 2018 yılında işsizlik oranı \%11 iken 2020 y1lında ilk altı aylık dönemde \%13,3'e kadar arttığı gözlemlenmiştir. Ayrıca, Covid-19'un en önemli etkilerinden biri dış ticarette ortaya çıkmış olup, TÜİK verilerine göre vakaları görülmeye ve hızla artmaya başlamış, 2020'nin ilk aylarından itibaren ihracat rakamları da bir önceki yıllara göre azalış göstermiştir (Eroğlu, 2020: 220-221).

Sonuç olarak, Covid-19’u 2008 küresel ekonomik krizi gibi diğer krizlerden farklı bir şekilde değerlendirmek gerekir. $\mathrm{Bu}$ durumda, birbirleri arasında bir karşılaştırmanın yapılmasını engelleyen bir çok güçlükler bulunmaktadır. Bu güçlükler; Covid-19'un tamamıyla dünya genelinde basit yaşanabilir, düşük ya da orta gelirli ülkelerden ziyade en gelişmiş kapitalist ülkelerde de kendini göstermesi, faiz oranlarının tarihi olarak en düşük seviyelerde olması, dünyanın her alanında entegre olması, tedarik zinciri boyunca yayılma etkisinin büyümesi ve aynı anda hem arzın hem de talebin etkileniyor olması şeklinde siralanabilir (Fernandes, 2020: 5). 


\subsection{Covid-19’un Değişen İş Modellerine Etkileri}

Covid-19 sürecinde dijitalleşme fırsatından yararlanmak için, firmaların dinamik olmaları ve çevresel değişikliklere karşı hayatta kalmalarına yardımcı olabilecek yetenekleri hızla geliştirmeleri gerekir. Bu tür dinamik yetenekler, ürünün yeniden geliştirilmesi ve mevcut kaynakları yeni değer yaratma stratejilerine dönüştürülmesi gibi belirli stratejik ve organizasyonel süreçlerle ilgilidir (Seetharaman, 2020: 3). Ayrıca, ürün ve hizmetin sunduğu dijitalleşme potansiyelini hızı bir şekilde yerine getirme hedeflenmelidir. Covid-19 sonrası durumun ortaya çıkardığ 1 yeni dengeye oturmak, kuruluşun stratejisinin, yapısının ve temel değerler, kontrol mekanizmaları ve yönetim bölümü dahil süreçlerinin altında yatan derin yapıların göz ardı edilmemesini gerektirir (Silva ve Hirschheim, 2007).

Covid-19 krizinin iş modelleri üzerindeki anlık etkisini analiz etmeye yardımcı olması için bilgi yoğunluğu matrisine ürünün ve hizmetin temel niteliğini eklemek gerekir. Bunu ayrıca, dinamikliğin stratejik zorunluluğunu, bazı endüstrilerdeki firmalara potansiyel bir iş modeli değişikliğini gerçekleştirmelerinde yardımcı olmada bir iş yeteneği olarak vurgulamak için kullanılır. Örneğin, bankacılık ve medya gibi endüstriler ürün ve süreç bilgi yoğunluğu açısından yüksektir ve bu da hizmetlerinin tamamen dijitalleştirilmesine olanak tanımaktadır (Seetharaman, 2020: 1-2). Ancak, dijital çalışmada ortaya çıkan belirli güçlüklerin üstesinden gelmek için de teknoloji, iş yoğunluğu, yönetici işçi ilişkileri, sosyal bağlantılar ve iş-ev sınırı olmak üzere potansiyel yönetim stratejileri uygulanmalıdır. Ayrıca, işletmelere uygun donanım, yazılım, eğitim ve teknik destek sağlanması yanında, çalışanların sanal bir ortamda çeşitli medyaları etkin bir şekilde kullanma becerilerini güçlendirmek için eğitimler verilmesi gerekir (Graves ve Karabayeva, 2020: 170).

Covid-19 salgını ile mücadelede, her sektörde sürdürülebilir iş modelleri için sosyoekonomik risk değerlendirmeleri ve stratejileri gereklidir. Covid-19 salgını, ürünlere ve hizmetlere yönelik talep modelini kökten değiştirmiş ve bu durum küresel ve bölgesel tedarik zincirlerinde ve ağlarında kırılganlık riskini artırmıştır. Firmalar yeni normalde faaliyetlerini sürdürebilmek için, operasyonel dayanıklılıklarını geliştirmeli, değer zinciri dijitalleşmesini hızlandırmalı, sermaye ve işletme giderlerinin şeffaflığını hızla artırmalı, uzaktan çalışmayı benimsemeli, sürdürülebilir operasyonları yeniden tasarlamalı ve rekabet gücü sağlamalıdır (Verma ve Gustafsson, 2020: 258). Bu doğrultuda, iş modellerinin dinamik pazarlara uyarlanması gerekmektedir.

Sonuç olarak, çoğu ülkede ana perakende süpermarketlerinin kısıtlama sırasında kapanmaktan muaf tutulmasına rağmen, çevrimiçi alışveriş yapan ve temel malzemeleri satan e-ticaret firmalarında önemli bir artış olduğu gözlemlenmiştir. Covid-19 krizi, yakın gelecekte kuruluşların dijital yeniden yapılanma aramasını veya ürünlerini ve hizmetlerini minimum fiziksel temasla ve güvenli bir şekilde sunmanın yollarını belirlemesini gerektirmiştir. $\mathrm{Bu}$ tercihler, firmalara mevcut ürünlerini yeniden tasarlarken yenilikçi olma firsatları sunmuştur. Bunların başlıcaları; alternatif dijital ürün ve hizmetlerin tasarlanması veya ürün ve hizmet sağlama kanallarını ve mekanizmalarını yeniden düşünmek ve yeni ekosistemde bunları başarmalarına yardımcı olabilecek stratejik pozisyonlar ve ortaklıklar geliştirmektir (Seetharaman, 2020: 2-4). 


\subsection{Covid-19’un İşletme Fonksiyonlarına Etkileri}

Bilgi teknolojisi projeleri ve teknolojik yetenekler, bu tür teknolojik şirketleri yakalamak için iş sürecini birbirine bağlayan girişimler için hayati önem taşımaktadır. $\mathrm{Bu}$ nedenle, bilişim ve teknoloji sınırı, borsada işlem gören işletmelerin iş performansını etkileyebilir ve bu da bir işletme için rekabet avantajı yaratır. Bu kurumsal faydalara rağmen, bilişim ve teknolojinin Türkiye'de rekabet avantajı yaratma yeteneği sorgulanmıştır. Benzer şekilde, dünyadaki bilişim ve teknolojideki gelişmeler, işletmelerin iş performansı ile ilgili kararlar almasını giderek daha fazla önemli hale getirmiştir (Akgün vd., 2018: 105).

Covid-19 pandemisi ile mücadele için kısıtlama ve sosyal mesafe koyma kurallarının yarattığı ekonomik kriz, genel olarak işletmeler için iyi bir uyarıcı çağrı olmuştur (Sheth, 2020b: 263). Böylece, işletmelerin içinde bulundukları ekonomik çevre, küreselleşme, bölgesel entegrasyonlar ve bilgi teknolojisindeki hızlı gelişmelerin yanı sıra Covid-19 pandemisi ile de sürekli bir değişim yaşamaktadır. Bu değişim, faaliyetlerini sürdürme durumunda olan işletmelerin iş yapma biçimlerinde ve genel işletme fonksiyonlarında da değişimi beraberinde getirmiştir (Akgün, 2020: 211). Bu çalışmada, işletmenin fonksiyonları; tedarik ve üretim, pazarlama, muhasebe ve finans, insan kaynakları, araştırma ve geliştirme, genel yönetim ve halka ilişkiler bağlamında ele alınmıştır.

\subsubsection{Tedarik ve Üretim Fonksiyonuna Etkisi}

Tedarik zinciri ağları, Covid-19'un küresel ekonomiyi olumsuz etkilediği önemli bir işletme fonksiyonudur. Farklı pazarlarda olduğu gibi, küresel tedarik zincirlerinin işleyişi mevcut kriz nedeniyle kesintiye uğramıştır. Ayrıca bu, tedarikçi ağlarının farklı seviyelerinde yayılma etkileri yaratmaktadır. Örneğin, otomobil şirketleri parça eksikliğinden operasyonlarını durdurma ile karşı karşıyadır (Fernandes, 2020: 12-13). Tedarik zincirlerindeki aksaklık, imalat şirketleri için işletme maliyetlerini artıracaktır.

Şirketler internet teknolojisini benimsedikçe, internetin kendisi de bir avantaj kaynağı olarak etkisiz hale gelecektir. İnternet teknolojisi, bir şirketin faaliyetlerini daha farklı bir sistemde birbirine bağlayarak avantajlarını güçlendirebilir. Tedarik bağlamında, stratejiye göre uyarlanmış internet ve geleneksel yöntemlerin bir kombinasyonunu içeriyorlarsa üretim ve satın alma daha etkili olacaktır (Porter, 2001: 18). Bu bağlamda, kâr güdüsünü aşan iş amacını enjekte etmek giderek daha gerekli hale gelmektedir (Sheth, 2020b: 263). Sonuçta, internet ile geleneksel rekabet avantajlarını ve rekabet yollarını bütünleştiren stratejiler birçok sektörde önem kazanacaktır.

\subsubsection{Pazarlama Fonksiyonuna Etkisi}

Covid-19, oteller, restoranlar ve barlar gibi konaklama işletmeleri için büyük bir kriz oluşturmuştur. Tüketiciler halka açık yerlerde diğer insanlardan kaçınma eğilimi göstermişlerdir. Böylece, krizde tüketici talebini sürdürmek için stratejik bir hareket kritik öneme sahiptir. Pek çok insan Covid-19'a tepki olarak malzeme stoklamış veya diğer insanlardan sosyal mesafeden kaçınmıştır. Hizmet bağlamında ise, tüketiciler restoran ve barları ziyaret etme konusunda da isteksiz davranmışlardır (Kim ve Lee, 2020: 67). Bu bağlamda, Covid-19 salgınının tüketim ve tüketici davranışı üzerindeki etkisini Sheth (2020); stoklama, doğaçlama, talebin ertelenmesi, dijital teknolojinin kucaklanması, mağazanın eve 
gelmesi, iş hayatı sınırlarının bulanıklaştırılması, arkadaşlar ve aile buluşmalarının sanallaşması ve yeteneklerin keşfi olmak üzere sekiz başlıkta ele almıştır.

\subsubsection{Muhasebe ve Finans Fonksiyonuna Etkileri}

Nakit akışı, bir firmanın ticari faaliyetlerinden kaynaklanan gelir akışı ve firma değerinin temel belirleyicisidir. Nakit akışlarının dönüşüm hızı hızlandıkça, çeşitli bileşenleri aracılığıyla üretilen nakit akışları ve gelecekteki nakit akışlarıyla ilişkili riskler azaltılır. Firmalar, Covid-19 sürecinde çeşitli pazarlama stratejileri ile nakit akışlarını artırabilirler. Örneğin, bir firma, ürünlerinin satış hacimlerini veya fiyatlarını artırarak ve farklı müşteri segmentlerine hizmet vererek nakit akışlarını artırabilir. Buna ek olarak, bir firma ürün yeniliklerini teşvik ederek, kurumsal sosyal sorumluluk programları başlatarak ve müşteri memnuniyetini artırarak nakit akışı riskini azaltabilir (Kang vd., 2020: 2).

Pandeminin etkileri çok geniştir ve dünyanın dört bir yanındaki insanlar, işletmeler ve hükümetler için geniş kapsamlı sonuçları vardır. Bununla birlikte, Covid-19 krizi, bireysel ve kurumsal düzeylerde çok çeşitli tepkilere yol açmıştır. Gelecekteki tepkiler için, muhasebe ve yönetim uygulamalarını, tedarik zinciri muhasebesi ve yönetimi ile ilgili konuları, örgütsel yanıtların araştırılmasını (revize etme, yeniden düzenleme ve yeniden icat etme) dikkate alınması gerekir (Rinaldi vd., 2020: 183).

Küreselleşme ile birlikte ortaya çıkan değişmelerle birlikle muhasebe disiplinlerinde olduğu gibi işletmeler için, yönetim muhasebesi de önemli bir işlev haline gelmiştir. Böylece, Covid-19, yönetim muhasebesinin uygulandığı ortam, bilişim teknolojileri, yüksek derecede rekabetçi ortam, yeni yönetim stratejileri, kalite ve müşteri hizmetlerini etkileyerek değişikliğe uğratmıştır. Bu tür değişiklikler faaliyetlere odaklanmayı zorunlu kılmış, ve yönetim muhasebesi uygulamaları; kalite maliyeti yönetimi, müşteri maliyetlerinin hesaplanması ve performans ölçümüne yönelik yaklaşım gibi yeni maliyet ve yönetim muhasebesi yaklaşımlarını beraberinde getirmiştir (Akgün, 2011: 49). Dolayısıyla, Covid-19 sürecinde ulusal ve uluslararası rekabet açısından işletmelerin önem verdiği öncelikli çalışmalar kalite ve kalite maliyetlerine odaklanmaktadır.

Covid-19 küresel krizine yanıt olarak işletmeler, maliyetleri düşürmek ve nakit akışlarını serbest bırakmak için tasarruf stratejileri veya hatta çıkış stratejileri (örneğin, ürün hatlarını azaltma, işgücünü küçültme veya iş faaliyetlerini durdurma) benimseyebilir. Ancak, bu müdahale stratejileri bazı firmalar için kısa vadede kaçınılmaz olsa da, uzun vadede bu firmaların büyümesine zarar verebilir. Bu durumda, uzun vadeli müdahale stratejileri genellikle tavsiye edilir. Örneğin, uzun vadede; kapsamlı pazar gelişimine önem vermek, yeni yatırımları hedeflemek, sebat etmek ve yenilik yapmak gerekir (Kang vd., 2020: 3).

\subsection{4. İnsan Kaynakları Fonksiyonuna Etkisi}

Covid-19 kısıtlamaları nedeniyle, işletmeler işteki çalışma saatlerini artırmı ücretleri ise düşürmüşlerdir. Birçok çalışan bu düşük ücretlerden veya gelir kaybından etkilenmiştir. Örneğin, seyahat ve turizm, yemek hizmetleri, perakende, imalat ve iş ve idari faaliyetler gibi sektörler en yüksek işsizlik ve eksik istihdam riski altındadır (Verma ve Gustafsson, 2020: 257). Covid-19 krizi ortaya çıktığında, işgücü piyasasının bu baskıyı nasıl üstlendiğine dair ilk belirti, işsizlik sigortası taleplerindeki dramatik artış olmuş ve istihdam oranı ile eksik 
istihdam oranında düşüşler yaşanmıştır (Bell ve Blanchflower, 2020: 52).

İkinci Dünya Savaşı'ndan bu yana en kötü küresel kriz olan Covid-19 salgını, halk sağlığını ciddi şekilde etkilemeye devam etmiş ve ekonomilerde ve işgücü piyasalarında benzeri görülmemiş aksamalara neden olmuştur. İşverenler ve kendi hesabına çalışanlar, düşük-orta gelirli ülkelerdeki neredeyse tüm kesimler etkilenmektedir, çünkü bunlar kayıt dış1lık düzeyi yüksek ekonomilerdir. İşyeri kapanışları, işletmelerin mevcut faaliyetleri üzerinde ani ve ciddi bir etkiye sahiptir ve onları yüksek iflas riskiyle karşı karşıya bırakır (ILO, 2020: 2). Dolayısıyla, hem işletmeleri hem de istihdamı korumak için acil desteğe ihtiyaç vardır.

Covid-19 işletmelere, teknolojik gelişmeleri etkin bir şekilde kullanmayı ve kurumların çalışma kültürüne entegre etmeyi öğretmiştir. Bu durumda insan kaynakları yönetimi (İKY), işi evden tanımlayarak önemli bir rol oynamıştır İKY, çalışma kültürlerine ve mevcut gereksinimlerine uyan belirli kısa vadeli ve uzun vadeli önlemleri uygulamaktadır. $\mathrm{Bu}$ mevcut önlemler nedeniyle geleneksel İKY'nin işlevleri değiştirilmiştir (Vasanthi ve Basariya, 2020: 41).

\subsubsection{AR-GE Fonksiyonuna Etkileri}

Covid-19 krizi sırasında işletmeler, rekabet avantajı sağlamak için daha hızlı çalışmışlardır. Firmalar, ortaya çıkan güçlükleri çözmek için krize tepki vermek yerine duyarlı yöntem ve süreçleri benimsemiş ve müşteri odaklı ve doğru yönetişimle desteklenen yeni işletim modellerine geçmişlerdir. Bu durum, işletmelerin nereye yatırım yapacaklarına karar vermelerini ve kaynaklarını yeniden tahsis etmelerini daha hızlı hale getirmiştir. Ayrıca, firmalar görünür, çevik ve üretken kalabilmek için AR-GE'ye önem vererek yeni ürün ve hizmetler yaratmaya ve bu süreçte kökten uyum sağlamaya zorlanmıştır (Verma ve Gustafsson, 2020: 255). Dolayısıyla, işletmeler için AR-GE fonksiyonu önemli hale gelmiştir.

Covid-19 krizi, şirketlerin inovasyon potansiyelini ciddi şekilde etkilemiş ve yeni girişimcilerin normal koşullar altında uygulanabilir olabilecek cesaretleri kırılmıştır. Yeni kurulan şirketlerin, faaliyetlerini sürdürmek için gereken sermaye ve gelir hızla kısıtlanmaya başladığından, kısa süre içinde iflas etmeye başlamışlardır. Bu nedenle, Covid-19 salgını sona erene kadar hayatta kalma, işe yeni başlayanların ve düzenleyicilerin birincil odak noktası olmalıdır. Ayrıca, kriz, risk sermayesi şirketlerinin yatırım modellerinde bir değişikliğe yol açarak odaklarını çevrimiçi market teslimatı, sağlık hizmetleri, hızlı tüketim malları ve ev eğlencesi gibi sektörlerde faaliyet gösteren girişimlere yöneltmiştir (Verma ve Gustafsson, 2020: 255-256).

\subsubsection{Yönetim Fonksiyonuna Etkileri}

Covid-19, yönetim fonksiyonu bazında planlama, örgütleme, koordinasyon ve denetimi etkilemiştir. Yöneticiler, sağlık bakanlığının ve bilim kurulunun tavsiyelerine uyarak sözü edilen yönetim fonksiyonlarını yerine getirmekle yükümlü olmuşlardır. Ayrıca, bu süreçte fiziksel aktivite sınırlandığından işletmenin tüm paydaşlarıyla iletişimi zayıflamış, buna karşın gelişen şartlara adapte olabilmek için koordinasyona ve kontrole olan ihtiyaç artmiştır. 
Covid-19 krizi, kuruluşların hesap verebilirliğini ve yönetişimini çevreleyen karmaşıklığı artırmıştır. Salgın sırasında toplumun karşılaştığı güçlükler, işletmelerin değişen doğası ve geçiciliği, sonuçların görülmemiş büyüklügünü yansıtmak için daha fazla maddi hesap verme uygulamalarına yönelik bir talep ortaya çıkarmıştır. Muhasebe ve hesap verebilirlik araştırmaları gelişip daha karmaşık hale gelirken, Covid-19 salgınının getirdiğ güçlükler, bu alandaki araştırmanın daha etkili hale gelmesi için hem bir zorluk hem de ihtiyaç sağlamaktadır (Rinaldi vd., 2020: 180).

Covid-19, halk sağlığ 1 sistemlerimizi ve bu krizden kurtulmak için gelecekte yönetim sistemlerimizi test edecektir. Covid-19 sonrası iyileşmede inovasyonun oynayacağı önemli bir rol olacaktır. Covid-19'un etkisi, bir dizi cesaret verici gelişmeye yol açmıştır. Bu gelişme, bilim adamlarının, ilaç şirketlerinin ve hükümet yetkililerinin virüse etkili bir yanıt bulmak için çeşitli bilimsel girişimler başlatmak üzere hızla harekete geçmelerine neden olmuştur. Bu gelişmelerin ortak noktası, bu hastalıkla mücadele etmek için dünyadaki mevcut beşeri sermayeden yararlanır ve ayrıca olası çözümlerin hızlı testlerini başlatmak için halihazırda mevcut olan tesis ve ekipman gibi fiziksel sermayeye erişmeleridir (Chesbrough, 2020: 410).

Üreticiler, hizmetlerin büyümesini sağlamak için giderek daha fazla dijitalleşmeye eğilmektedirler. Bununla birlikte, başarı garanti olmaktan uzaktır ve birçok firma teknolojiye çok fazla odaklanmaktadır. Tronvoll vd. (2020), üst düzey yöneticiler ile yaptıkları görüşmelere göre, dijital hizmet odaklı büyümeyi başarmak için bir firma ve ağının birbiriyle bağlantılı (1) planlamadan keşfe, (2) kıtlıktan bolluğa, ve (3) hiyerarşiden ortaklığa olmak üzere üç aşamada olması gerektiğini ortaya koymuştur. Ayrıca, dijitalleşmenin sağladığı daha fazla açıklık ve şeffaflık, bunu geleneksel organizasyonlardan daha kritik hale getirmektedir. Dijital hizmetler büyük ölçüde yazılım geliştirme ve dijital altyapının yaşam döngüleri tarafından koşullandırıldığı için çevik bir zihniyet geliştirmek de çok önemli hale gelmektedir. Ayrıca dijital hizmet sağlama, bilgi ve yeterlilikler gerektirir. Bununla ilgili olarak, endüstriyel pazarlar veri hacimleri ve yazılım kullanıcılarının sayısı açısından tüketici pazarlarından farklılık gösterdiğinden, veriye dayalı tekliflerin uygun ölçeklenebilirliğini sağlamak önemlidir (Tronvoll vd., 2020: 302-303).

\subsubsection{Halka İlişkiler Fonksiyonuna Etkileri}

Müşteri ilişkileri yönetimi, müşterileri tanımlama, müşteri bilgisi oluşturma, müşteri ilişkileri kurma ve firma ve ürünleri hakkındaki algılarını şekillendirmenin tüm yönlerini içermektedir. Covid-19 salgını, müşterilere hayatlarında birçok önemli değişikliğe (örneğin evde yemek pişirme, çevrimiçi alışveriş ve güvenlik, deneyim ve rahatlıkla ilgilenme gibi) neden oldu ve bu nedenle, işletmeler müşterilerin yeni alışkanlıklarını ve endişelerini tatmin etmek için bir dizi teklif sunmalıdır. Mevcut ve potansiyel yeni müşterilerin ihtiyaçlarını karşılamak için reklam, promosyon, hizmet ve satış programları gibi pazarlama programları geliştirmek ve yürütmek, krizdeki firmalar için gereklidir. Örneğin, bir fïma hem yeni iş hem de müşteri kazanmak için bir müşteri yönlendirme ödül programı yapabilir. Ayrıca, işletmeler, müşteri güvenini ve bağlılığını artırmak için müşteri iletişimi için bilgi teknolojisi ve sisteminden yararlanabilir. Örneğin, sosyal medya ve mobil teknolojiler, dinamik alıc1satıcı etkileşimleri ve genel bilgilerin yayılması için kullanılabilir (Kang vd., 2020: 5). 


\section{ARAŞTIRMANIN YÖNTEMI}

Bu çalışmada, Covid-19'un işletmelere ve işletme fonksiyonlarına etkisi ele alınmıştır. $\mathrm{Bu}$ bağlamda, Ankara Yıldırım Beyazıt Üniversitesi Sağlık Bilimleri Fakültesinin sağlık yönetimi lisans bölümü ile Sağlık Yönetimi Tezli Yüksek lisans öğrencilerinin Covid-19'un işletmelere ve işletme fonksiyonlarına etkisine yönelik öneriler ortaya konmuştur. $\mathrm{Bu}$ çalışmada, nitel araştırma yöntemlerinden durum çalışması tekniğinden yararlanılmıştır. Durum çalışması ise nitel araştırmalarda kullanılan önemli yöntemlerden biri olup, özellikle araştırmacıların bir konuya ait durumu, genellikle bir programı, olayı, eylemi, süreci ya da bir veya daha fazla bireyi derinlemesine değerlendiren bir araştırma yöntemidir (Akgün, 2020: 221). Bu çalışmadaki nitel veri, açık uçlu soru listesi ile toplanmıştır. Ancak bu veri, sayısallaştırılarak, betimsel tarama (alan) araştırması yöntemi kullanılmıştır.

Covid-19 süreci ile, Türkiye'deki bütün örgün eğitim yapan Üniversiteler 13 Mart 2020 tarihinden sonra, zorunlu olarak bahar dönemi eğitimlerini uzaktan eğitim ile yapmaya başlamışlardır. Araştırmada veri toplama aracı olarak 12 Ekim 2020 tarihinde Ankara Yıldırım Beyazıt Üniversitesi Uzaktan Eğitim Araştırma ve Uygulama Merkezi sistemi kullanılarak, İşletme I dersini alan öğrencilerin Covid-19'un işletme fonksiyonlarına etkilerine yönelik görüşleri alınmıştır. Söz konusu araştırmada öğrencilere herhangi bir anket uygulanmayıp, öğrencilerin görüşleri belirlenmeye çalışılmıştır. Araştırmanın verileri ise, Excel'de oluşturulan tablolar yardımıyla betimleyici analizler ve frekans dağılımları bazında değerlendirilmiştir.

Bu araştırmada, Ankara Yıldırım Beyazıt Üniversitesi Sağlık Yönetimi bölümünde okuyan İşletme I dersine kayıt yaptıran 82 lisans ve 6 yüksek lisans olmak üzere 88 öğrencinin vize sınavı yerine geçerli olmak üzere Covid-19'un işletme fonksiyonlarına olan etkisinin tartışılması istenmiştir. Söz konusu araştırmada öğrencilere herhangi bir anket uygulanmayıp, öğrencilerin kendi görüşleri belirlenmeye çalışılmıştır. Çalışmanın amacı, işletme eğitimi alan öğrencilerin Covid-19 ile işletme fonksiyonlarına etkilerini değerlendirmelerinde yeni ufuklar sunmaktır. Araştırmanın örneklemi aşağıdaki Tablo 1'de verilmiştir.

Tablo 1. Araştırmaya İlişkin Örneklem

\begin{tabular}{|c|l|l|l|l|l|l|}
\hline & Erkek & Kız & Toplam & $\begin{array}{l}\text { Sinava } \\
\text { Katılan } \\
\text { Erkek }\end{array}$ & $\begin{array}{l}\text { Sinava } \\
\text { Katılan } \\
\text { Kız }\end{array}$ & $\begin{array}{l}\text { Sinava } \\
\text { Katılan } \\
\text { Toplam }\end{array}$ \\
\hline Lisans & 16 & 66 & 82 & 14 & 56 & 70 \\
\hline Yükseklisans & 2 & 4 & 6 & 2 & 4 & 6 \\
\hline Toplam & $\mathbf{1 8}$ & $\mathbf{7 1}$ & $\mathbf{8 8}$ & $\mathbf{1 6}$ & $\mathbf{6 0}$ & $\mathbf{7 6}$ \\
\hline
\end{tabular}

Tabloya göre, İşletme I dersini alan 88 öğrenci olup, araştırmaya ilişkin örneklemin $\% 20,45$ 'i erkek ve $\% 79,55$ 'i ise kız öğrencilerden oluşmaktadır. Tablo 1'e göre, İşletme I dersini alan lisans öğrencilerinin \%85,36'si sınava katılmış olup, bunların \%20,00'si erkek ve \%80,00'i de kız öğrencilerden oluşmaktadır. Ayrıca, araştırmanın örnekleminin \%93,18'si lisans öğrencilerinden oluşmaktadır. $\mathrm{Bu}$ verilere göre yüksek lisans öğrencilerine ait örneklemimiz toplam mevcudun \%100'ünü teşkil etmektedir. 


\section{BULGULAR}

Ankara Yıldırım Beyazıt Üniversitesi Sağlık Yönetimi bölümünde lisans ve yüksek Lisans düzeyinde okuyan ve İșletme I dersinde sınava giren öğrencilerin Covid-19'un işletme fonksiyonlarına etkisini içeren görüşlerine ilişkin frekans dağılım tabloları aşağıda verilmiştir.

Tablo 2. Covid-19'un İşletme Fonksiyonlarına Etkisi (Lisans)

\begin{tabular}{|c|c|c|c|c|c|}
\hline Tedarik ve Üretim Fonksiyonu & $\mathrm{K} 1 \mathrm{z}$ & Erkek & Toplam & $\mathrm{K}(\%)$ & $\mathrm{E}(\%)$ \\
\hline $\begin{array}{l}\text { Hastalığın başlarında tüketiciler gerekli olmayan bir çok ürün satın almaları dolayısıyla tüketim } \\
\text { alışkanlığında değişikliğe yol açmıştır. }\end{array}$ & 6 & 3 & 9 & 66,67 & 33,33 \\
\hline $\begin{array}{l}\text { İnsanlar dezenfektan, eldiven ve maske gibi ürünleri stoklaması ile, bu gibi ürünleri satan } \\
\text { firmalarınn daha fazla üretim yapmalarına ve çeşit arttırmalarına yol açmıştır.. }\end{array}$ & 12 & 5 & 17 & 70,59 & 29,41 \\
\hline $\begin{array}{l}\text { Covid-19 sebebiyle üretim faaliyetlerinin neredeyse tamamen durmuş, ihtiyaç duyulan hammadde } \\
\text { ve malzeme veya mamulün yetersiz kalmasına sebep olmuştur. Global tedarik faaliyetlerinin } \\
\text { aksamasının, üretim sisteminin de aksamasına neden olmuştur. Miktarın, zamanın ve kaynağın } \\
\text { azalmasıyla fiyatlar artmıştır. Fiyatların artmasıyla satışlar durmuş ve gerileme söz konusu } \\
\text { olmuştur. }\end{array}$ & 25 & 9 & 34 & 73,53 & 26,47 \\
\hline $\begin{array}{l}\text { Üretilen hammadde ve sunulan hizmetin arz edilenden düşük olması, hammaddeye ve hizmete } \\
\text { ulaşmayı güçleștirmiş ve maliyetleri artırmıştır. }\end{array}$ & 10 & 2 & 12 & 83,33 & 16,67 \\
\hline $\begin{array}{l}\text { Bazı işletmeler için, yeni ürün ve hizmetler sunarak satışları artırmak, satış ve pazarlama } \\
\text { giderlerinin azalması ile kaynakların daha iyi kullanılması, müşteri hizmetlerinin kalitesinin artması } \\
\text { olarak nitelendirilebilir. }\end{array}$ & 6 & 3 & 9 & 66,67 & 33,33 \\
\hline \multicolumn{6}{|l|}{ Pazarlama Fonksiyonu } \\
\hline Online alış verişe olan talep artmıştır. & 33 & 8 & 41 & 80,49 & 19,51 \\
\hline $\begin{array}{l}\text { Covid-19 nedeniyle toplu çalışmalar, bir arada bulunmalar tehlike arz etmeye başlamıştır. Bu } \\
\text { sebeple de pazarlama fonksiyonu daha zor bir hale gelmiştir. Dağıtım süreci zorlaşmış ve neredeyse } \\
\text { durma noktasına gelmesi, hem üreticileri hem satıcıları hem de alıcıları olumsuz etkilemiştir. }\end{array}$ & 6 & 3 & 9 & 66,67 & 33,33 \\
\hline Covid-19 virüsü pazarlamanın tutundurma faaliyetini etkin kılmıștır. & 2 & 2 & 4 & 50,00 & 50,00 \\
\hline $\begin{array}{l}\text { İşletmelerin neredeyse her tür ekonomik faaliyeti durmuş, küresel tedarik zinciri bozulmuş; sadece } \\
\text { sağlık, gıda, iletişim gibi temel hizmet veren işkolları ve belirli temel ürünleri üreten sektörler ile } \\
\text { online uzaktan hizmet veren ve evlere servis yapan işletmeler faaliyetine devam edebilmişlerdir. }\end{array}$ & 4 & 3 & 7 & 57,14 & 42,86 \\
\hline \multicolumn{6}{|l|}{ Muhasebe ve Finans Fonksiyonu } \\
\hline $\begin{array}{l}\text { Covid-19’un sonucunda nakit akış döngülerinde de zincirleme sıkıntılar meydana gelmiş ve } \\
\text { işletmelerin alacaklarının tahsilinde güçlüğe yol açmıştır. }\end{array}$ & 24 & 9 & 33 & 72,73 & 27,27 \\
\hline $\begin{array}{l}\text { Özellikle stok yönetimi ve finansal planlamada güçlüklere neden olmuştur. Ayrıca, ürünün } \\
\text { işlenememesi ve hizmetin sunulamaması stok alımını ve yatırımı yapılamaz hale getirmiştir. }\end{array}$ & 8 & 6 & 14 & 57,14 & 42,86 \\
\hline $\begin{array}{l}\text { Azalan talep ve ne zaman artacağının belirsizliğiyle bozulan tedarik zinciri, işletmelerde nakit ve } \\
\text { işletme sermayesi sorunlarına yol açıyor. }\end{array}$ & 8 & 5 & 13 & 61,54 & 38,46 \\
\hline $\begin{array}{l}\text { COVID-19 işletmelerin ödemekte olduğu kredi borçları yönünden onları büyük güçlüğe itmiştir. } \\
\text { İşletmeler krediyi ödeyemeyince hukuki yönden çatışma içine girmişlerdir }\end{array}$ & 5 & 4 & 9 & 55,56 & 44,44 \\
\hline \multicolumn{6}{|l|}{ İnsan Kaynakları Fonksiyonu } \\
\hline $\begin{array}{l}\text { Online çalışma durumlarında çalışanların performanslarını ve yeteneklerini görmek güçleşetiğinden } \\
\text { olumsuz bir etkiye sahiptir. Çalışanların motivasyonları da bu durumda olumsuz etkilenmiştir. }\end{array}$ & 6 & 2 & 8 & 75,00 & 25,00 \\
\hline Çalışmaları denetlemek ve değerlendirmek de haliyle güçleşmiştir. & 3 & 1 & 4 & 75,00 & 25,00 \\
\hline Covid 19 ile, stratejik insan kaynaklarına yönelik kararlar alınması daha da önemli hale gelmiştir. & 3 & 1 & 4 & 75,00 & 25,00 \\
\hline İşçi alımları azalmış hatta işçiler işsiz kalmıştır. & 8 & 4 & 12 & 66,67 & 33,33 \\
\hline $\begin{array}{l}\text { Nitelikli işgücünün elde tutulmasını sağlamak adına ücret, kariyer planlaması, moral ve motivasyon } \\
\text { uygulamalarının son derece önemli olduğu, özellikle firmaların çalışanlarını elde tutabilmek adına } \\
\text { pandemi döneminde kariyer planlama programlarını gözden geçirmesi gerektiği ortaya çıkmıştır. }\end{array}$ & 4 & 1 & 5 & 80,00 & 20,00 \\
\hline $\begin{array}{l}\text { Firmalar, ihtiyaç duydukları iş gücünü temin etmede internetten yararlanmakta, değerlendirme ve } \\
\text { mülakat gibi süreçleri de yine internet aracıllığılla gerçekleştirmektedir. }\end{array}$ & 4 & 1 & 5 & 80,00 & 20,00 \\
\hline $\begin{array}{l}\text { Planlama süreci yapılırken işletmelerde bulunan çalışanların en az sayıda bulunmasına, çalışanların } \\
\text { çoğunun ev ortamından işlerini sürdürmelerine imkan sağlanmıştır. }\end{array}$ & 2 & 1 & 3 & 66,67 & 33,33 \\
\hline \multicolumn{6}{|l|}{ AR-GE Fonksiyonu } \\
\hline $\begin{array}{l}\text { Covid-19 ile tüketicilerin davranışlarının değişmesi ve rekabet ortamlarının da artması, işletmeleri } \\
\text { araştırma ve geliştirme için yenilik yapmaya itmiştir. }\end{array}$ & 2 & 1 & 3 & 66,67 & 33,33 \\
\hline $\begin{array}{l}\text { İşletmelerin rekabet halinde olmaları için araştırma ve geliştirme konusunda ilerlemesi olumlu } \\
\text { yönden etkilenmiştir. }\end{array}$ & 3 & 1 & 4 & 75,00 & 25,00 \\
\hline
\end{tabular}




\begin{tabular}{|c|c|c|c|c|c|}
\hline Dijital işbirliğinin artması işletmelerin ortak ürün tasarımını teşvik etmiştir. & 3 & 2 & 5 & 60,00 & 40,00 \\
\hline $\begin{array}{l}\text { Covid-19’un teşhis ve tedavisinde kullanılan ürünlerin geliştirilmesine yönelik AR-GE projeleri ön } \\
\text { plana çıkarmıştır. }\end{array}$ & 2 & 1 & 3 & 66,67 & 33,33 \\
\hline \multicolumn{6}{|l|}{ Yönetim Fonksiyonu } \\
\hline $\begin{array}{l}\text { Yöneticilerin işletmede daha güvenli bir iş ortamı sağlamaları gerekmiştir. Bununla beraber } \\
\text { yöneticinin idare etmesi gereken personel saysı azalmıştır. Ancak, sağlı açsından daha tehlikeli bir } \\
\text { ortamda çalıştıkları için eskiye göre daha dikkatli, yoğun ve kimi işletmelerin daha uzun süreli } \\
\text { çalışması gerekmiştir. }\end{array}$ & 3 & 0 & 3 & 100,00 & - \\
\hline $\begin{array}{l}\text { Covid-19 un etkisini sürdürdüğü süre boyunca yönetimde de alınacak kararlar yüz yüze toplanmak } \\
\text { yerine online olarak yapılmaya devam etmesiyle, ortaya çıacak kriz durumlarında kriz anını } \\
\text { yönetmek oldukça zorlaşacaktır. Bundan dolayı da alınacak kararlar ve uygulanacak sistemler } \\
\text { oldukça önemlidir. }\end{array}$ & 4 & 2 & 6 & 66,67 & 33,33 \\
\hline $\begin{array}{l}\text { Yöneticilerin daha dikkatli planlama yapmalarını, çalışanlarını daha iyi korumak için hem sağlık } \\
\text { destekleri ve çalışma şekline dair yeni yaklaşımlar üretmelerini, teknolojik alt yapılarını gözden } \\
\text { geçirmelerini, iş sürekliliği ve kriz yönetimini etkin kılmak için koordinasyon sağlamaları gerekir. }\end{array}$ & 6 & 1 & 7 & 85,71 & 14,29 \\
\hline $\begin{array}{l}\text { Yöneticiler aldığı her kararda işletmenin ve çalışanların zararını en az boyuta indirmenin, } \\
\text { çalışanların sağlığını ve güvenliğini sağlamanın, tüketiciye kaliteli bir hizmet sağlamanın en uygun } \\
\text { ve verimli yollarını öncelik edinmişlerdir. }\end{array}$ & 3 & 1 & 4 & 75,00 & 25,00 \\
\hline $\begin{array}{l}\text { Hızla değişen ekonomik ve ticari koşullar göz önüne alındığında, yönetimin başlangıçta yapmış } \\
\text { olduğu süreklilik değerlendirmesini desteklemek için kullanılmış olabilecek bütçeler ve tahminler } \\
\text { mevcut koşullarda yeterli olmayabileceğinden ötürü önemli bir revizyon gerektirebilir. }\end{array}$ & 3 & 1 & 4 & 75,00 & 25,00 \\
\hline \multicolumn{6}{|l|}{ Halka İlişkiler Fonksiyonu } \\
\hline $\begin{array}{l}\text { Halkla ilişkilerde işletmenin basın bülteni ve lansmanlar da stratejik açıdan önemli bir yere sahiptir. } \\
\text { Bu durumda covid-19 olduğu süreçte basın toplantılarını ve lansmanları olumsuz etkilenmiştir. } \\
\text { Çünkü şirketlerin kriz anını ve herhangi bir şirketin haberinden haberdar olmamız şu durumda } \\
\text { insanlar için ön planda değildir. }\end{array}$ & 3 & 0 & 3 & 100,00 & - \\
\hline $\begin{array}{l}\text { Halkla ilişkiler işletme ve diğer kurumlarda daha sağlıklı ilişkiler kurmak için önemli insan } \\
\text { kaynaklı olması ile bu süreçten olumsuz etkilenmiştir. }\end{array}$ & 2 & 0 & 2 & 100,00 & - \\
\hline $\begin{array}{l}\text { Bu süreçte kurumların gerçekleştirdiği kriz yönetimi ve kriz iletişimi hakkında önemli } \\
\text { değerlendirmeler yapılmıştır. Ayrıca, bu mücadelede bilgi kirliliğinden uzak, doğru } \\
\text { bilgilendirmeler ve doğru iletişimin kurulmasına önem göstermektedir. }\end{array}$ & 1 & 0 & 1 & 100,00 & - \\
\hline
\end{tabular}

Tablo 2'de görüldüğü üzere, lisans öğrencilerine göre, tedarik ve üretim fonksiyonu için, üretilen ham madde ve hizmetin arz edilenden az olması, ham maddeye ve hizmete ulaşmayı güçleştirmesi ve maliyeti artırması kız öğrenciler açısından \%83,33 ile 1.inci sırada görüş olarak ifade edilmiştir. Bu görüş, literatürdeki Fernandes (2020)'in çalışmasıyla benzerlik göstermektedir. Kız öğrencilerin \%73,53 ile 2.inci sırada görüş olarak, Covid-19 sebebiyle üretim faaliyetlerinin neredeyse tamamen durmasına ve ihtiyaç duyulan hammadde ve malzeme veya mamulün yetersiz kalmasına sebep olmuştur. Global tedarik faaliyetlerinin aksaması, üretim sisteminin de aksamasına ve fiyatların artmasıyla da satışların düşmesine neden olduğunu belirtmişlerdir. Ayrıca, kız öğrencilerin \%70,59'u insanların dezenfektan, eldiven ve maske gibi ürünler almaya başlayınca bu gibi ürünleri satan firmaların ve üreticilerin fazla üretim yapmaya ve çeşit arttırmaya başlamasını 3.üncü sırada etki olarak ifade etmişlerdir. Bu görüş ise, Sheth (2020)'nın çalışmalarındaki bulgular ile benzerlik göstermektedir.

Konuya erkek öğrenciler açısından baktığımızda, Covid-19 sürecinin başlarında insanlar söylentiler üzerine aslında gerekli olmayan bir çok ürünü satın alması dolayısıyla tüketim alışkanlığında değişikliğe yol açması \%33,33 oran ile birinci sırada yer almaktadır. Ayrıca, Covid-19 sebebiyle üretim faaliyetleri neredeyse tamamen durmuş ve bu duraksama ihtiyaç duyulan hammadde ve malzeme veya mamulün yetersiz kalmasına sebep olmuştur. Global tedarik faaliyetlerinin aksamasının, üretim sisteminin de aksamasına ve fiyatların artmasıyla satışların düşmesine neden olduğunu belirtmişlerdir.

Pazarlama fonksiyonuna olan etkilere göre, online alış verişe olan talebin artması kız öğrenciler açısından \%80,49 ile 1.inci sırada görüş olarak ifade edilmiştir. Bu görüş ise, Sheth 
(2020)'nın çalışmalarındaki tüketici davranışlarına yönelik değişimin sonuçlarından mağazanın eve gelmesi bulguları ile benzerlik göstermektedir. Kız öğrencilerin \%73,53 ile 2.inci sırada görüş olarak, Covid-19 nedeniyle toplu çalışmalar ve bir arada bulunmalar tehlike arz etmeye başlamıştır. Bu sebeple de pazarlama fonksiyonu daha güç bir hale gelmesi, dağıtım sürecini zorlaştırmış ve neredeyse durma noktasına gelmesi, hem üreticileri hem satıcıları hem de alıcıları olumsuz etkilemiştir. Konuya erkek öğrenciler açısından baktığımızda, Covid-19 pandemisi, pazarlamanın tutundurma faaliyetini etkin kılmas1 \%50,00 ile birinci sırada etkiye sahipken, işletmelerin neredeyse her tür ekonomik faaliyeti durmuş, küresel tedarik zinciri bozulmuş; sadece sağlık, gıda, iletişim gibi temel hizmet veren işkolları ve belirli temel ürünleri üreten sektörler ile online uzaktan hizmet veren ve evlere servis yapan işletmeler faaliyetine devam edebilmeleri ise \%42,86 ile ikinci sırada öncelikli görüşleri arasında yer almıştır.

Muhasebe ve finans fonksiyonuna etkilerine göre, kız öğrenciler açısından Covid19'un sonucunda nakit akış döngülerinde de zincirleme sıkıntılar meydana getirmiş ve işletmelerin alacaklarının tahsilinde güçlük çekmeleri \%72,73 ile 1.inci sırada görüş olarak ifade edilmiştir. Kız öğrencilerin \%61,54 ile 2.inci sırada görüş olarak, azalan talep ve ne zaman artacağının belirsizliğiyle bozulan tedarik zinciri, işletmelerde nakit ve işletme sermayesi sorunlarına yol açtığını belirtmişlerdir. Bu görüş ise, Kang vd. (2020)'nın çalışmalarındaki bulgular ile benzerlik göstermektedir. Konuya erkek öğrenciler açısından baktığımızda, Covid-19 işletmelerin ödemekte olduğu kredi borçları yönünden onları büyük güçlüğe itmiştir. İşletmeler krediyi ödeyemeyince hukuki yönden çatışma içine girmelerini \%44,44 ile 1.inci sırada görüş olarak ifade edilmiştir. İkinci olarak da erkek öğrencilerin \%42,86's1 pandeminin, özellikle stok yönetimi ve finansal planlamada güçlüklere neden olduğunu belirtmiştir. Ayrıca, ürünün işlenememesi ve hizmetin sunulaması stok alımını ve yatırımları etkilediğini ifade etmişlerdir.

İnsan kaynakları fonksiyonu açısından etkilerine baktığımızda, kız öğrenciler açısından nitelikli işgücünün elde tutulmasını sağlamak için ücret, kariyer planlaması, moral ve motivasyon uygulamalarının son derece önemli olduğu ve kariyer planlama programlarını gözden geçirmeleri gerektiği \%80,00 ile 1.inci sırada görüş olarak ifade edilmiştir. Bu görüş ise, Vasanthi ve Basariya (2020)'nın çalışmalarındaki bulgular ile benzerlik göstermektedir. $\mathrm{K} 1 \mathrm{z}$ öğrencilerin $\% 75,00$ 'i ise 2.inci sırada görüş olarak, online çalışma durumunda çalışanların performanslarını ve yeteneklerini görmek güçleştiğinden olumsuz bir etkiye sahiptir. Çalışanların motivasyonları da bu durumda olumsuz etkilenir. Ayrıca, Covid-19 ile çalışmaları denetlemek ve değerlendirmek de haliyle güçleşmesi, stratejik insan kaynaklarına yönelik kararlar alınması daha da önemli hale gelmesini belirtmiştir.

Konuya erkek öğrenciler açısından baktığımızda, işçi alımlarının azalması ile planlama süreci yapılırken işletmede bulunan çalışanların en az sayıda olmasına, çalışanların çoğunun ev ortamından işlerini yürütmelerine imkan sağlaması \%33,33 ile 1.inci sırada görüş olarak ifade edilmiştir. Ayrıca, erkek öğrencilerin \%25,00'i ise 2.inci sırada görüş olarak, , online çalışma durumunda çalışanların performanslarını ve yeteneklerini görmek güçleştiğinden olumsuz bir etkiye sahiptir. Çalışanların motivasyonları da bu durumda olumsuz etkilenir. Ayrıca, Covid-19 ile çalışmaları denetlemek ve değerlendirmek de haliyle güçleşmesi, stratejik insan kaynaklarına yönelik kararlar alınması daha da önemli hale gelmesini belirtmiştir. 
AR-GE fonksiyonu açısından etkilerine baktığımızda, kız öğrenciler açısından işletmelerin rekabet halinde olmaları için araştırma ve geliştirme konusunda ilerlemesi olumlu yönden etkilenmesi \%75,00 ile 1.inci sırada görüş olarak ifade edilmiştir. Kız öğrencilerin \%75,00'i ise 2.inci sırada görüş olarak, Covid-19 ile tüketicilerin davranışlarının değişmesi ve rekabet ortamlarının da artması işletmelerin araştırma ve geliştirme için yenilik yapmaya doğru itmesi ile Covid-19 sürecindeki teşhis ve tedavisinde kullanılan ürünlerin geliştirilmesine yönelik AR-GE projelerinin ön plana çıkması ifade edilmiştir. Bu görüş ise, Verma ve Gustafsson (2020)'nın çalışmalarındaki bulgular ile benzerlik göstermektedir. Konuya erkek öğrenciler açısından baktığımızda, dijital işbirliğinin artması işletmelerin ortak ürün tasarımını teşvik etmesi \%40,00 ile 1.inci sırada görüş olarak ifade edilmiştir. Erkek öğrencilerin \%33,33’ü ise 2.inci sırada görüş olarak, Covid-19 ile tüketicilerin davranışlarının değişmesi ve rekabet ortamlarının da artması araştırma ve gelişme için yenilik yapmaya doğru itmesi ile Covid-19 sürecindeki teşhis ve tedavisinde kullanılan ürünler ve ekipmanların geliştirilmesine yönelik AR-GE projeleri ön plana çıkmasını önemli etki olarak ifade etmişlerdir.

Yönetim fonksiyonu açısından etkilerine baktığımızda, kız öğrencilere göre, yöneticilerin işletmede daha güvenli bir iş ortamı sağlamalarının gerekmesi, yöneticinin idare etmesi gereken insan sayısı azalması ve sağlık açısından daha tehlikeli bir ortamda çalıştıkları için eskiye göre daha dikkatli, yoğun ve kimi işletmelerin daha uzun süreli çalışması gerekmesi \%100,00 ile 1.inci sırada görüş olarak ifade edilmiştir. Kız öğrencilerin \%85,71'i ise 2.inci sırada görüş olarak, yöneticilerin daha dikkatli planlama yapmalarını, çalışanlarını daha iyi korumak için hem sağlık destekleri ve çalışma şekline dair yeni yaklaşımlar üretmelerini, teknolojik alt yapılarını gözden geçirmelerini, iş sürekliliği ve kriz yönetimini etkin kılmak için koordinasyon sağlamaları gerektiğini ifade etmişlerdir. Bu görüş ise, Chesbrough (2020)'nın çalışmalarındaki bulgular ile benzerlik göstermektedir. Konuya erkek öğrenciler açısından baktığımızda, Covid-19'un etkisini sürdürdüğü süre boyunca yönetimde de alınacak kararlar yüz yüze toplanmak yerine online olarak yapılmaya devam edecektir. Bu durumda ortaya çıkacak kriz durumlarında kriz anını yönetmek oldukça zorlaşacaktır. Bundan dolayı da alınacak kararlar ve uygulanacak sistemlerin oldukça önemli olması \%33,33 ile 1.inci sırada görüş olarak ifade edilmiştir.

Halka ilişkiler fonksiyonuna olan etkilerine baktığımızda, kız öğrencilere göre, halkla ilişkilerde işletmenin basın bülteni ve lansmanlar da stratejik açıdan önemli bir yere sahiptir. $\mathrm{Bu}$ durumda covid-19 olduğu süreçte basın toplantılarını ve lansmanlarını olumsuz etkilemiştir. Çünkü şirketlerin kriz anları ve herhangi bir şirketin haberinden haberdar olmamız şu durumda insanlar için ön planda değildir. Halkla ilişkiler, işletme ve diğer kurumlarda daha sağlıklı ilişkiler kurmasına yönelik süreçlerin insan kaynaklı olması bu süreçten olumsuz etkilenmiştir. Bu süreçte kurumların gerçekleştirdiği kriz yönetimi ve kriz iletişimi hakkında önemli değerlendirmeler yapılması ve ayrıca bu mücadelede bilgi kirliliğinden uzak, doğru bilgilendirmeler ve doğru iletişimin kurulmasına önem gösterilmesi $\% 100,00$ ile 1.inci sırada görüş olarak ifade edilmiştir. Buna karşılık, işletme fonksiyonlarından olan halka ilişkiler fonksiyonuna yönelik olarak erkek öğrencilerden görüş beyan eden olmamıştır. 
Tablo 3. Covid-19'un İşletme Fonksiyonlarına Etkisi (Yükseklisans)

\begin{tabular}{|c|c|c|c|c|c|}
\hline Tedarik ve Üretim Fonksiyonu & $\mathrm{K} 1 \mathrm{Z}$ & Erkek & Toplam & $\mathrm{K}(\%)$ & $\mathrm{E}(\%)$ \\
\hline $\begin{array}{l}\text { Mal ve hizmetlerin üretim maliyeti artmış işletmeler zarar etmeye başlamışlardır. Durum böyle } \\
\text { olunca işten çıkarımlar artmış, satışlar azalmış, fiyatlar yükselmiştir. }\end{array}$ & 2 & 1 & 3 & 66,67 & 33,33 \\
\hline $\begin{array}{l}\text { Covid-19 sebebiyle üretim faaliyetleri neredeyse tamamen durması, ihtiyaç duyulan hammadde ve } \\
\text { malzeme veya mamulün yetersiz kalmasına sebep olmuştur. Tedarik faaliyetlerinin aksaması, } \\
\text { üretim sisteminin de aksamasına neden olmuştur. Miktarın, zamanın ve kaynağın azalmasıyla } \\
\text { fiyatlar artmışır. Fiyatların artmasıyla satışlar durmuş ve gerilemiştir. }\end{array}$ & 4 & 2 & 6 & 66,67 & 33,33 \\
\hline $\begin{array}{l}\text { Üretilen hammadde ve hizmetin arz edilenden az olması, ham maddeye ve hizmete ulaşmayı } \\
\text { güçleştirmiş ve maliyetleri artırmıştır. }\end{array}$ & 2 & 1 & 3 & 66,67 & 33,33 \\
\hline Dezenfektan, eldiven ve maske gibi ürünleri satan firmalar, çeşitlerini arttırmışlardır. & 2 & 1 & 3 & 66,67 & 33,33 \\
\hline $\begin{array}{l}\text { Covid tedavisinde kullanılan malzemeleri üreten bir şirketin hammadde alımını, üretim yönetimini, } \\
\text { stok durumunu artan talebe göre yeniden uyarlaması gerekmektedir. Buna karşın talebi düşen bir } \\
\text { tekstil işletmesinin ne kadar kumaş alacağını üretime devam edip etmeyeceğini ya da ne kadar } \\
\text { üretim yapacağını bu üretimi stoklayıp stoklayamayacağını ya da ne kadar süreliğine } \\
\text { stoklayabileceğini yeniden gözden geçirmesi gerekecektir. }\end{array}$ & 2 & 0 & 2 & 100,00 & - \\
\hline \multicolumn{6}{|l|}{ Pazarlama Fonksiyonu } \\
\hline Online alış verişe olan talep artmıştır. & 2 & 2 & 4 & 50,00 & 50,00 \\
\hline $\begin{array}{l}\text { Covid-19 pandemisi nedeniyle tüketicilerin ihtiyaçlarında ve taleplerinde oluşan değişim nedeniyle } \\
\text { pazarlanan ürünlerin içeriğinde de değişimler meydana gelmiştir. }\end{array}$ & 2 & 1 & 3 & 66,67 & 33,33 \\
\hline \multicolumn{6}{|l|}{ Muhasebe ve Finans Fonksiyonu } \\
\hline İşletmeler salgın döneminde finansal açıdan büyük zorluklar yaşamaktadırlar. & 4 & 1 & 5 & 80,00 & 20,00 \\
\hline $\begin{array}{l}\text { Salgının oluşturduğu belirsizlik ortamında işletmeler daha az riskli yatırımlara ve kaynak } \\
\text { arayışlarına girmişlerdir. }\end{array}$ & 3 & 1 & 4 & 75,00 & 25,00 \\
\hline $\begin{array}{l}\text { Covid-19’un etkileri sonucunda azalan, eski haline ne zaman döneceği belli olmayan talep ve } \\
\text { bozulan tedarik zinciri, satışların düşmesi gibi faktörler işletmeleri finansal yönde etkilemektedir. }\end{array}$ & 2 & 1 & 3 & 66,67 & 33,33 \\
\hline $\begin{array}{l}\text { Tüketicilerin harcama miktarındaki ve ürün taleplerindeki değişim, işletmelerde muhasebe } \\
\text { işlemlerini etkilemektedir. }\end{array}$ & 2 & 1 & 3 & 66,67 & 33,33 \\
\hline \multicolumn{6}{|l|}{ İnsan Kaynakları (ÍK) Fonksiyonu } \\
\hline $\begin{array}{l}\text { Planlama süreci yapılırken işletmedeki çalışanların en az sayıda bulunmasına ve ev ortamından } \\
\text { çalışmalarını sürdürmelerine imkan sağlanmıştır. }\end{array}$ & 2 & 0 & 2 & 100,00 & - \\
\hline $\begin{array}{l}\text { İK kriz ortamında işletmenin entelektüel sermayesinin iyi bir durumda tutulmasını temin etmelidir. } \\
\text { Ayrıca, personelin yeni durumun gereklerine adapte olabilmesi ve güncel kalabilmesi için ilave } \\
\text { eğitimler alması gerekebilir. Bu durumda İK gerekli planlama ve organizasyonları } \\
\text { gerçekleştirmelidir. }\end{array}$ & 2 & 0 & 2 & 100,00 & - \\
\hline $\begin{array}{l}\text { Pandemi sürecinde klasik mesai anlayışının esnetilmesi bir zorunluluk olmuşken, İKY’nin } \\
\text { kendisini bu duruma adapte ederek performans değerleme, motivasyon, çalışma barışını sağlama, } \\
\text { ücret adaleti gibi birçok işlevini uzaktan çalışmaya uyarlaması gerekmektedir. }\end{array}$ & 2 & 0 & 2 & 100,00 & - \\
\hline \multicolumn{6}{|l|}{ AR-GE Fonksiyonu } \\
\hline AR-GE çalışanlarının ekipman kaynaklı araştırma yapmalarını zorlaştırmıştır. & 2 & 1 & 3 & 66,67 & 33,33 \\
\hline $\begin{array}{l}\text { Covid-19 tedavisinde kullanılan sağlı malzemelerini üreten ya da çevirim içi toplantı olanakları } \\
\text { sağlayan bir yazılım şirketinin ARGE harcamalarının artması beklenirken, krizle bu şekilde ilişkisi } \\
\text { olmayan diğer sektörlerin ARGE harcamalarının ve dolayısıyla ARGE faaliyetlerinin düşmesi } \\
\text { beklenebilir. }\end{array}$ & 2 & 0 & 2 & 100,00 & - \\
\hline \multicolumn{6}{|l|}{ Yönetim Fonksiyonu } \\
\hline $\begin{array}{l}\text { İşletmeler tamamen bütün dünyaya yabancı bir salgının etkilerini ve bulaşma yollarını bilmedikleri } \\
\text { için ilk başta alınan bütün kararlar bir bilinmezlikle alınmış ve bu da çalışanlar ve yönetenler için } \\
\text { bir kaos ve korku ortamı oluşturmuştur. }\end{array}$ & 2 & 0 & 2 & 100,00 & - \\
\hline $\begin{array}{l}\text { Yönetim fonksiyonunu da yerine getiren kişiler yani yöneticiler sağlık bakanlığının yayınladığı } \\
\text { kurallara uyarak yönetim fonksiyonlarını yerine getirmekle yükümlü olmuşlardır. }\end{array}$ & 2 & 0 & 2 & 100,00 & - \\
\hline $\begin{array}{l}\text { Bu süreçte fiziksel aktivite sınırlandığından işletmenin bütün paydaşlarıyla iletişimi zayıflamakta, } \\
\text { buna karşın gelişen şartlara adapte olabilmek için koordinasyona ve kontrole olan ihtiyaç } \\
\text { artmaktadır. Buna göre işletme yönetimi fiziksel aktivitenin yavaşladığı salgın sürecinde özellikle } \\
\text { teknolojinin nasıl kullanılarak etkili bir koordinasyonun sağlanacağını belirlemelidir. }\end{array}$ & 2 & 0 & 2 & 100,00 & - \\
\hline \multicolumn{6}{|l|}{ Halka İlişkiler Fonksiyonu } \\
\hline $\begin{array}{l}\text { Covid-19 ile, işletmenin paydaşları olan ortaklar ve yatırımcılar, personel, müșteriler, kredi } \\
\text { kuruluşları, kanun koyucu ve vergi otoritesi olarak devlet, toplum ile olan iletişimini kriz } \\
\text { yönetiminin gereklerine uygun olarak yönetmesi ve bu da şirketin ayakta kalmasına ve hedeflerini } \\
\text { gerçekleştirmesine yardım edecek şekilde motive etmesine yol açmaktadır. }\end{array}$ & 2 & 0 & 2 & 100,00 & - \\
\hline
\end{tabular}

Tablo 3'de yer aldığg üzere, yüksek lisans yapan kız öğrencilerin tamamı, tedarik ve üretim fonksiyonu için, Covid tedavisinde kullanılan malzemeleri üreten bir şirketin 
hammadde alımını, üretim yönetimini ve stok durumunu artan talebe göre yeniden uyarlaması gerekmesi görüşünü savunmaktadır. Bu görüş, literatürdeki Fernandes (2020)'in çalışmasıyla benzerlik göstermektedir. K1z öğrencilerin \%66,67 ile erkek öğrencilerin \%33,33’ü 2.inci sırada görüş olarak, Covid-19 sebebiyle üretim faaliyetlerinin neredeyse tamamen durmas1, ihtiyaç duyulan hammadde ve malzeme veya mamulün yetersiz kalmasına sebep olmuştur. Tedarik faaliyetlerinin aksaması, üretim sisteminin de aksamasına neden olması fiyatların artmasıyla satışların düşmesine yol açmıştır. Üretilen hammadde ve sunulan hizmetin arz edilenden düşük olması, hammaddeye ve hizmete ulaşmayı güçleştirmiş ve maliyeti artırdığını ifade etmişlerdir. Bu görüşler ise, Sheth (2020)'nın çalışmalarındaki bulgular ile benzerlik göstermektedir. Ayrıca, dezenfektan, eldiven ve maske gibi ürünleri satan firmalar, daha fazla üretim yapmaya başladılar ve ürünün çeşidini artırmaları hem kız hem de erkek öğrenciler açısından \%33,33’ü 2.inci sırada görüş olarak ifade edilmiştir.

Pazarlama fonksiyonuna olan etkilere göre, Covid-19 pandemisi nedeniyle tüketicilerin ihtiyaçlarında ve taleplerinde oluşan değişim nedeniyle pazarlanan ürünlerin içeriğinde de değişimler meydana gelmesi kız öğrenciler açısından \%66,67 ile 1.inci sırada görüş olarak ifade edilmiştir. Ayrıca, online alış verişe olan talebin artması kız öğrenciler açısından \%50,00 ile 2.inci sırada görüş olarak ifade edilmiştir. Bu görüş ise, Sheth (2020)'nın çalışmalarındaki tüketici davranışlarına yönelik değişimin sonuçlarından mağazanın eve gelmesi bulguları ile benzerlik göstermektedir. Kız öğrenciler açısından 2.görüş olarak, online alış verişe olan talebin artması görülürken, erkek öğrenciler açısından ise \%50,00 ile 1.inci sırada görüş olarak ifade edilmiştir. İkinci olarak erkek öğrencilerin \%33,33’ü, Covid-19 pandemisi nedeniyle tüketicilerin ihtiyaçlarında ve taleplerinde oluşan değişim nedeniyle pazarlanan ürünlerin içeriğinde de değişimler meydana geldiğini savunmaktadır.

Muhasebe ve finans fonksiyonuna etkilerine göre, kız öğrenciler açısından işletmeler salgın döneminde finansal açıdan büyük zorluklar yaşamaları \%80,00 ile 1.inci sırada görüş olarak ifade edilmiştir. Bu görüş ise, Kang vd. (2020)'nın çalışmalarındaki bulgular ile benzerlik göstermektedir. Salgının oluşturduğu belirsizlik ortamında işletmelerin daha az riskli yatırımlara ve kaynak arayışlarına girmeleri \%75,00 ile 2.inci sırada görüş olarak ifade edilmiştir. Konuya erkek ögrenciler açısından baktığımızda, Covid-19'un etkileri sonucunda azalan, eski haline ne zaman döneceği belli olmayan talep ve bozulan tedarik zinciri, satışların düşmesi gibi faktörler işletmeleri finansal yönde etkilemektedir. Tüketicilerin harcama miktarındaki ve ürün taleplerindeki değişim, işletmelerde muhasebe işlemlerini etkilemesi \%33,33 ile 1.inci sırada görüş olarak ifade edilmiştir. Ayrıca, Covid-19'un oluşturduğu belirsizlik ortamında işletmelerin daha az riskli yatırımlara ve kaynak arayışlarına girmeleri $\% 25,00$ ile 2.inci sırada görüş olarak ifade edilmiştir.

İnsan kaynakları fonksiyonu açısından etkilerine baktı̆̆ımızda, kız öğrenciler açısından planlama süreci yapılırken işletmelerdeki çalışanların en az sayıda bulunmasına ve ev ortamından çalışmalarını sürdürmelerine imkan sağlanmıştır. İK kriz ortamında işletmenin entelektüel sermayesinin iyi bir durumda tutulmasını temin etmelidir. Ayrıca, personelin yeni durumun gereklerine adapte olabilmesi ve güncel kalabilmesi için ilave eğitimler alması gerekebilir. $\mathrm{Bu}$ durumda, İK gerekli planlama ve organizasyonları gerçekleştirmelidir. Pandemi sürecinde klasik mesai anlayışının esnetilmesi bir zorunluluk olmuşken, insan kaynakları yönetiminin kendisini bu duruma adapte ederek performans değerleme, motivasyon, çalışma barışını sağlama, ücret adaleti gibi birçok işlevini uzaktan çalışmaya 
uyarlaması gerekmesi \%100,00 ile 1.inci sırada görüş olarak ifade edilmiştir. Bu görüş ise, Vasanthi ve Basariya (2020)'nın çalışmalarındaki bulgular ile benzerlik göstermektedir. Buna karşılık, işletme fonksiyonlarından olan insan kaynakları fonksiyonuna yönelik olarak erkek öğrencilerden görüş beyan eden olmamıştır.

AR-GE fonksiyonu açısından etkilerine baktığımızda, kız öğrenciler açısından Covid19 tedavisinde kullanılan sağlık malzemelerini üreten ya da çevirim içi toplantı olanakları sağlayan bir yazılım şirketinin ARGE harcamalarının artması beklenirken, krizle bu şekilde ilişkisi olmayan diğer sektörlerin ARGE harcamalarının ve dolayısıyla AR-GE faaliyetlerinin düşmesi beklenmesi \%100,00 ile 1.inci sırada görüş olarak ifade edilmiştir. Kız öğrencilerin \%66,67 ile 2.inci sırada görüş olarak, AR-GE çalışmalarının ekipman kaynaklı araştırma yapmalarını zorlaştırmıştır. Konuya erkek öğrenciler açısından baktığımızda, virüs kaynaklı AR-GE çalışmaları insanların evlerinde olduğundan ekipman kaynaklı araştırmacıların araştırma yapmalarını zorlaştırması \%33,33 ile 1.inci sırada görüş olarak ifade edilmiştir.

Yönetim fonksiyonu açısından etkilerine baktığımızda, kız öğrencilere göre, işletmeler tamamen bütün dünyaya yabancı bir salgının etkilerini ve bulaşma yollarını bilmedikleri için ilk başta alınan bütün kararlar bir bilinmezlikle alınmış ve bu da çalışanlar ve yönetenler için bir kaos ve korku ortamı oluşturmuştur. Yönetim fonksiyonunu da yerine getiren kişiler yani yöneticiler sağlık bakanlığının yayınladığı kurallara uyarak yönetim fonksiyonlarını yerine getirmekle yükümlü olmuşlardır. Ayrıca, bu süreçte fiziksel aktivite sınırlandığından işletmenin bütün paydaşlarıyla iletişimi zayıflamakta, buna karşın gelişen şartlara adapte olabilmek için koordinasyona ve kontrole olan ihtiyaç artmaktadır. Buna göre işletme yönetimi fiziksel aktivitenin yavaşladığı salgın sürecinde özellikle teknolojinin nasıl kullanılarak etkili bir koordinasyonun sağlanacağını belirlemesi \%100,00 ile 1.inci sırada görüş olarak ifade edilmiştir. Buna karşılık, işletme fonksiyonlarından olan yönetim fonksiyonuna yönelik olarak erkek öğrencilerden görüş beyan eden olmamıştır.

Halka ilişkiler fonksiyonuna olan etkilerine baktığımızda, kız öğrencilere göre, kriz zamanında doğru iletişim kurulamazsa toplum tarafından firsatçı, krizin yükünü topluma ya da personeline yıkan, salt kar hırsıyla hareket eden bir işletme görüntüsü verebilir. Bu durum işletmenin imajını ve değerini olumsuz yönde etkileyebilir. Buna göre işletmenin paydaşları olan ortaklar ve yatırımcılar, personel, müşteriler, kredi kuruluşları, kanun koyucu ve vergi otoritesi olarak devlet, içinde yaşanılan toplum vs. ile olan iletişimini kriz yönetiminin gereklerine uygun olarak yönetmesi ve bu paydaşları şirketin ayakta kalmasına ve hedeflerini gerçekleştirmesine yardım edecek şekilde motive etmesi gerekmesi $\% 100,00$ ile 1 .inci sırada görüş olarak ifade edilmiştir. Buna karşılık, işletme fonksiyonlarından olan halka ilişkiler fonksiyonuna yönelik olarak erkek öğrencilerden görüş beyan eden olmamıştır.

\section{SONUÇ}

$\mathrm{Bu}$ çalışma, Covid-19'un işletme fonksiyonlarına yaptığ 1 etkiler ile işletme yöneticilerinin işletmenin olağandışı taleplerini karşılamak ve sürdürülebilir iş uygulamaları geliştirmek için stratejiler, hizmetler ve ürünlerdeki hangi değişikliklerin gerekli olduğunu anlamak için stratejik bir yaklaşım benimsemek isteyen yöneticilere fayda sağlayabilir.

Araştırma bulguları değerlendirildiğinde, sınava katılan lisans öğrencilerinden kız öğrencilerin çoğunluğu, tedarik ve üretim fonksiyonu için, üretilen hammadde ve hizmetin arz 
edilenden az olması, ham maddeye ve hizmete ulaşmayı güçleştirdiğini ifade etmişlerdir. Bu görüş, literatürdeki Fernandes (2020)'in çalışmasıyla benzerlik göstermektedir. Konuya erkek öğrenciler açısından baktığımızda, Covid-19 sürecinin, tüketicilerin tüketim alışkanlığında değişikliğe yol açması sınava katılanların üçte birinin savunduğu öncelikli görüş olmuştur. Pazarlama fonksiyonuna olan etkilere göre, online alış verişe olan talebin artması kız öğrenciler açısından çoğunlukla öncelikli görüş olarak ifade edilmiştir. Bu görüş ise, Sheth (2020)'nın çalışmalarının bulguları ile benzerlik göstermektedir. Konuya erkek öğrenciler açısından baktığımızda, Covid-19 pandemisi, pazarlamanın tutundurma faaliyetini etkin kılması sınava katıların yarısının birinci sırada savunduğu görüşleri arasında yer almıştır. Muhasebe ve finans fonksiyonuna etkilerine göre, kız öğrenciler açısından Covid19'un sonucunda nakit akış döngülerinde de zincirleme sıkıntılar meydana gelmiş ve işletmeler alacakların tahsilinde güçlük çekmeleri sınava katılanların üçte ikisinin öncelikli görüşü olarak ifade edilmiştir. Konuya erkek öğrenciler açısından baktığımızda, sınava katıların yaklaşık yarısı COVID-19 işletmelerin ödemekte olduğu kredi borçları yönünden onları büyük güçlüğe ittiği ifade etmişlerdir.

İnsan kaynakları fonksiyonu açısından etkilerine baktığımızda, kız öğrenciler açısından işletmelerin ihtiyaç duydukları iş gücünü temin etmede, işe alımların değerlendirmesi ve mülakat süreçlerinin de internet aracılığıyla gerçekleştirmesinin çoğunlukla öncelikli savunduğu görüş olarak ifade edilmiştir. Bu görüş ise, Vasanthi ve Basariya (2020)'nın çalışmalarındaki bulgular ile benzerlik göstermektedir. Konuya erkek öğrenciler açısından baktığımızda, planlama ve koordinasyon süreci yapılırken işletmede bulunan çalışanların en az sayıda olmasına ve çalışmaların ev ortamından yürütülmesine imkan sağlaması nedeniyle iş motivasyonunun olumsuz etkilendiğini belirtmişlerdir.

AR-GE fonksiyonu açısından etkilerine baktığımızda, kız öğrenciler açısından işletmelerin Covid-19 sürecindeki teşhis ve tedavisinde kullanılan ürünler, ekipmanlar ve hastalığın önlenmesinde etkili olan ürünlerin geliştirilmesine yönelik AR-GE projeleri ön plana çıkarmıştır. Bu görüş ise, Verma ve Gustafsson (2020)'nın çalışmalarındaki bulgular ile benzerlik göstermektedir. Konuya erkek öğrenciler açısından baktığımızda, Covid-19 ile dijital işbirliğinin artması işletmelerin ortak ürün tasarımını teşvik etmesi sınava katılan öğrencilerin yaklaşık yarısının öncelikli görüşü olarak ifade edilmiştir. Yönetim fonksiyonu açısından etkilerine baktığımızda, kız öğrencilere göre, Covid-19 yöneticilerin daha dikkatli planlama ve koordinasyon yapmalarına, çalışanlarını korumak için hem sağlı destekleri ve çalışma şekline dair yeni yaklaşımlar geliştirmelerine yol açmıştır. Konuya erkek öğrenciler açısından baktığımızda, Covid-19 un etkisini sürdürdüğü süre boyunca yönetimde de alınacak kararlar yüz yüze toplanmak yerine online olarak yapılmaya devam edeceğinden, ortaya çıkacak kriz durumlarında kriz anını yönetmek oldukça güçleşecektir. Ayrıca, halka ilişkiler fonksiyonuna olan etkilerine baktığımızda, kız öğrencilere göre, halkla halkla ilişkiler, işletme ve diğer kurumlarda daha sağlıklı ilişkiler kurmak için gerekli olduğu için bu süreçten olumsuz etkilenmiştir. Buna karşılık, işletme fonksiyonlarından olan halka ilişkiler fonksiyonuna yönelik olarak erkek öğrencilerden görüş beyan eden olmamıştır.

Yüksek lisans öğrencilerine göre, tedarik ve üretim fonksiyonu için, Covid tedavisinde kullanılan malzemeleri üreten bir şirketin hammadde alımını, üretim yönetimini ve stok durumunu artan talebe göre yeniden uyarlaması gerekmesi kız öğrenciler açısından çoğunlukla 1.inci sırada görüş olarak ifade edilmiştir. Bu görüş, literatürdeki Fernandes (2020)'in çalışmasıyla benzerlik göstermektedir. Araştırma bulgularına göre, erkek 
öğrencilerin yaklaşık üçte biri, Covid-19 sebebiyle üretim faaliyetlerinde ortaya çıkan duraksama, ihtiyaç duyulan hammadde ve malzeme veya mamulün yetersiz kalmasına sebep olduğunu, bununda hammaddeye ve hizmete ulaşmayı güçleştirdiğini birincil etki olarak ifade etmişlerdir. Bu görüşler ise, Sheth (2020)'nın çalışmalarındaki bulgular ile benzerlik göstermektedir. Pazarlama fonksiyonuna olan etkilere göre, Covid-19 pandemisi nedeniyle tüketicilerin ihtiyaçlarında ve taleplerinde oluşan değişim nedeniyle pazarlanan ürünlerin içeriğinde de değişimler meydana gelmesi kız öğrenciler açısından sınava katıların üçte ikisinin 1.inci sırada savunduğu görüş olarak ifade edilmiştir. Konuya erkek öğrenciler açısından baktığımızda, online alış verişe olan talebin artması sınava katılanların yarısının 1.inci sırada savunduğu görüş olarak ifade edilmiştir.

Muhasebe ve finans fonksiyonuna etkilerine göre, kız öğrenciler açısından işletmelerin salgın döneminde finansal açıdan büyük güçlükler yaşamaları sınava katılanların çoğunluğu ile 1.inci sırada savunduğu görüş olarak ifade edilmiştir. Bu görüş ise, Kang vd. (2020)'nın çalışmalarındaki bulgular ile benzerlik göstermektedir. Konuya erkek öğrenciler açısından baktığımızda, Covid-19'un etkileri sonucunda azalan, eski haline ne zaman döneceği belli olmayan talep ve bozulan tedarik zinciri, satışların düşmesi gibi faktörler işletmeleri finansal yönde etkilediği sonucuna varılmıştır. İnsan kaynakları fonksiyonu açısından etkilerine baktığımızda, kız öğrenciler açısından planlama süreci ayarlanırken işletmelerde bulunan çalışanların en az sayıda bulunmasına, çalışanların çoğunun ev ortamından işlerini sürdürmelerine imkan sağladığı belirtilmiştir. AR-GE fonksiyonu açısından etkilerine baktığımızda, kız öğrenciler açısından Covid-19 tedavisinde kullanılan sağlık malzemelerini üreten ya da çevirim içi toplantı olanakları sağlayan bir yazılım şirketinin ARGE harcamalarının artması beklenirken, erkek öğrenciler açısından AR-GE çalışmalarının, araştırmacıların araştırma yapmalarını güçleştirdiği sonucuna varılmıştır.

Yönetim fonksiyonu açısından etkilerine baktığımızda, kız öğrencilere göre, Covid-19 ile fiziksel aktivite sınırlandığından işletmenin bütün paydaşlarıyla iletişimi zayıflamakta, buna karşın gelişen şartlara adapte olabilmek için koordinasyona ve kontrole olan ihtiyaçların artması sınava katılanların tamamının 1.inci sırada savunduğu görüş olarak ifade edilmiştir. Halka ilişkiler fonksiyonuna olan etkilerine baktığımızda, kız öğrencilere göre, Covid-19 ile işletmenin paydaşları olan ortaklar, yatırımcılar, personel, müşteriler, kredi kuruluşları, kanun koyucu ve vergi otoritesi olarak devlet, toplum ile olan iletişimini kriz yönetiminin gereklerine uygun olarak yönetmesi ve bu da şirketin ayakta kalmasına ve hedeflerini gerçekleştirmesine yardım edecek şekilde motive etmesi gerektiğini öncelikli savundukları görüş olarak ifade etmişlerdir.

Covid-19, yöneticilerin işletmede daha güvenli bir iş ortamı sağlamalarını ve işçilerin sağlık açısından daha tehlikeli bir ortamda çalışmaları nedeniyle eskiye göre daha dikkatli koordinasyon sağlamalarını gerektirmiştir. Ayrıca, işletmenin yönetim kurulu toplantıları için yönetimde de alınacak kararlar yüzyüze toplanmak yerine online olarak yapılmaya başlanması, ortaya çıkacak kriz durumlarında kriz anını yönetmek ve koordine etmeyi güçleştirmiştir. Covid-19 ve bundan sonraki muhtemel krizlere hazırlıklı olmak bağlamında ulusal ve uluslararası ölçekte risk yönetim stratejileri izlenmelidir. Ayrıca, yöneticiler performans odaklı bütçeleme sistemlerini uygulayarak işletmenin gelecekteki planlamasını, örgütlenmesini ve koordinasyonunu güncel hale getirmeleri gerekir. 


\section{KAYNAKLAR}

Akgün, Ali İ. (2020), "COVID-19 sürecinde acil durum uzaktan eğitimi yoluyla verilen muhasebe eğitimine yönelik öğrenci görüşleri”, Açıköğretim Uygulamaları ve Araştırmaları Dergisi, 6(4), ss.208-236.

Akgün, Ali İ. (2011), "Kalite Maliyetlerinin Muhasebeleştirilmesi”, Muhasebe ve Vergi Uygulamaları Dergisi, 1(4), ss.49-79.

Akgün, Ali İ.- Şamiloglu, Famil - Öztop, Ali O. (2018), “The Impact of Profitability on Market Value Added: Evidence from Turkish Informatics and Technology Firms”, International Journal of Economics and Financial Issues, 8(4), pp.105-112.

Anh, D.L.T. - Gan, C. (2020), The Impact of the COVID-19 Lockdown On Stock Market Performance: Evidence From Vietnam, Journal of Economic Studies, doi:10.1108/JES- 06-2020-0312.

Al-Awadhi, A.M.- Al-Saifi, K.- Al-Awadhi, A. - Alhamadi, S. (2020), "Death and Contagious Infectious Diseases: Impact of the COVID-19 Virus On Stock Market Returns”, Journal of Behavioral and Experimental Finance, 27, doi: 10.1016/j.jbef.2020.100326.

Alfaro, L., Chari, A.- Greenland, A.N. - Schott, P.K. (2020), Aggregate and Firm-Level Stock Returns during Pandemics, in Real Time, Working Paper No. w26950, National Bureau of Economic Research, Massachusetts.

Ashraf, B.N. (2020), “Stock Markets’ Reaction to COVID-19: Cases or Fatalities?”, Research in International Business and Finance, 54, doi: 10.1016/j.ribaf.2020.101249.

Bell, David N.F. - Blanchflower, D.G. (2020), "US and UK Labour Markets Before and During the COVID-19 Crash”, NatioNal iNstitute ecoNomic Review, 252, pp.52-69.

Chesbrough, H. (2020), “To Recover Faster from Covid-19, Open Up: Managerial Implication from an Open İnnovation Perspective”, Industrial Marketing Management, 88, pp.410- 413.

Donthu, N. - Gustafsson, A. (2020), "Effects of Covid-19 on Business and Research”, Journal of Business Research, 117, pp.284-289.

Eroğlu, E. (2020), “Covid-19’un Ekonomik Etkilerinin ve Pandemiyle Mücadele Sürecinde Alınan Ekonomik Tedbirlerin Değerlendirilmesi”, International Journal of Public Finance, 5(2), ss.211-236.

Evenett, S. J. (2020), "Sicken Thy Neighbour: The Initial Trade Policy Response to COVID19”, World Econ. 43, pp.828-839.

Fernandes, N. (2020), "Economic Effects of Coronavirus Outbreak (COVID-19) On The World Economy”, Electronic copy available at: https://ssrn.com/abstract=3557504.

Graves, L.M. - Karabayeva, A. (2020), “Managing Virtual Workers-Strategies for Success”, 
IEEE Engineering Management Review, 48(2), pp.166-172.

Goodell, J.W. (2020), COVID-19 and Finance: Agendas For Future Research, Finance Research Letters, 35, 101512.

He, P., Sun, Y.- Zhang, Y. - Li, T. (2020), “COVID-19's Impacticepon Stock Prices Across Different Sectors-An Event Study Based on the Chinese Stock Market”, Emerging Markets Finance and Trade, 56:10, pp.2198-2212.

ILO (2020), ILO Monitor:isepe-iCOVID-19 and the World Of Work, Third edition Updated Estimates And Analysis, pp.1-23.

Jorda, O.- Singh, S.R. - Taylor, A.M. (2020), Longer-Run Economic Consequences of Pandemics. Federal Reserve Bank of San Francisco Working Paper 2020-09, Available at https://doi.org/10.24148/wp2020-09.

Kang, J.- Diao, Z. - Zanini, M.T. (2020), "Business-to-business Marketing Responses to COVID-19 Crisis: A Business Process Perspective”, Marketing Intelligence \& Planning, DOI:10.1108/MIP-05-2020-0217.

Kim, J. - Lee, J.C. (2020), "Effects of COVID-19 on Preferences For Private Dining Facilities in Restaurants”, Journal of Hospitality and Tourism Management, 45, pp.67-70.

Liu, H.- Manzoor, A.- Wang, C., Zhang, L. - Manzoor, Z. (2020), “The COVID-19 Outbreak And Affected Countries Stock Markets Response”, International Journal of Environmental Research and Public Health, 17(8), doi: 10.3390/ijerph17082800.

Orhangazi, Ö. (2020), Türkiye Ekonomisinin Yapısı Sorunlar Kırılganlıklar ve Kriz Dinamikleri, İmge Kitabevi, Ankara.

Ozili, Peterson K. (2020), COVID-19 in Africa: Socioeconomic Impact, Policy Response And Opportunities, Online at https://mpra.ub.uni-muenchen.de/99617/ MPRA Paper No. 99617.

Ozili, P. - Arun, T. (2020), Spillover of COVID-19: Impact on the Global Economy. Online at https://mpra.ub.uni-muenchen.de/99850/ MPRA Paper No. 99850.

Porter, M. E. (2001), “Strategy and the Internet”, Harvard Business Review, 79(3), pp.62-78.

Rinaldi, L.- Cho, C.H.- Lodhia , S.K.- Michelon, G. - Tilt, C.A. (2020), “Accounting in Times of the COVID-19 Pandemic: A Forum For Academic Research”, Accounting Forum, 44(3), pp.180-183.

Seetharaman, P. (2020), “Business Models Shifts: Impact of Covid-19”, International Journal of Information Management 54, 102173.

Sheth, J. (2020), "Impact of Covid-19 on Consumer Behavior: Will The Old Habits Return Or Die?”, Journal of Business Research, 117, pp.280-283. 
Sheth, J. (2020b), "Business of Business is More Than Business: Managing During The Covid Crisis”, Industrial Marketing Management, 88, pp.261-264.

Tronvoll, B.- Sklyar, A.- Sörhammar, D. - Kowalkowski, C. (2020), “Transformational Shifts Through Digital Servitization”, Industrial Marketing Management, 89, pp.293-305.

Vasanthi, S. - Basariya, S.R. (2020), “Impact of Covid-19 on HRM Functions”, International Journal of Business and Management Invention (IJBMI), 9(6), pp.39-42.

Verma, S. - Gustafsson, A.sLE: (2020), "Investigating the Emerging COVID-19 Research Trends in the Field of Business And Management: A Bibliometric Analysis Approach”, Journal of Business Research, 118, pp.253-261.

Zhang, D.- Hu, M. - Ji, Q. (2020), "Financial Markets Under The Global Pandemic of COVID-19”, Finance Research Letters, 36, 101528. 
